\section{DECLASSIFIED}

MONTHLY REPORTS

JANUARY - OCTOBER 1970

PRODUCTION REACTOR BRANCH

P.L. PLUM

USAEC RICHLAND OPERATIONS
PRD - - 102

DE93 012072

APR 19 1993
OS 1 i

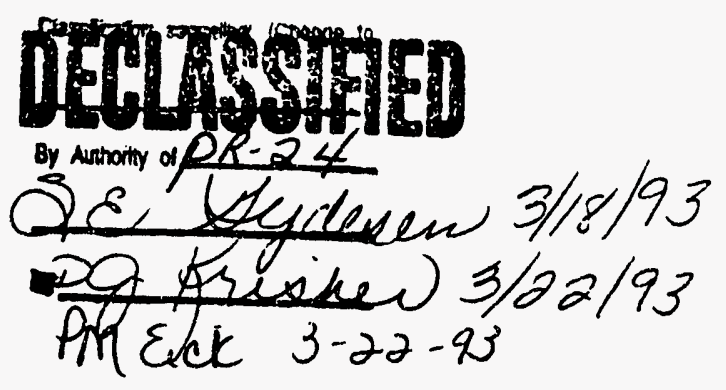

DECLASSIFIED

MASTER 


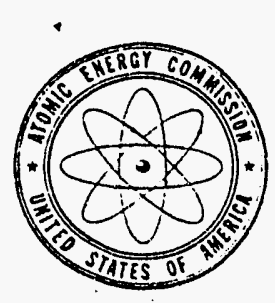

\section{तहल \\ $8 x^{3}$ a \\ UNITED STATES \\ ATOMIC ENERGY COMMISSION}

RICHLAND OPERATIONS OFFICE

P. O. BOX 550

RICHLAND, WASHINGTON 99352

HANFORD CATEMOS:

November 16,1970

Piles

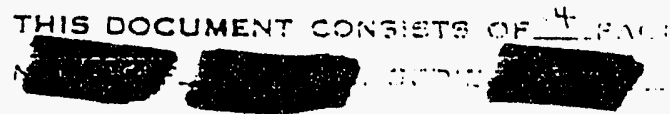

L.IONTHLY REPORT FOR OCTOBER. 1970

SUREIARY

The equilibrium power level was restricted to $3800 \mathrm{~kW}$ by brittle

fracture tube power limits. There was one scheduled charge-

discharge outage during the month.

REACTOR OPERATIOIS AITD ILAINTENAICE

\section{Operation}

Input KIND

io of Forecast

T.O.E.

Operational Limitation

Ruptures

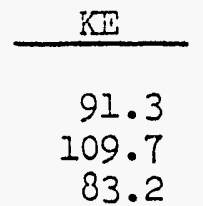

Tube Power

0

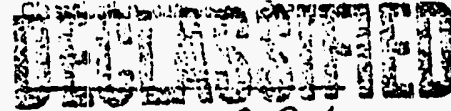

By Aurnoity of $\subseteq R \cdot 24$

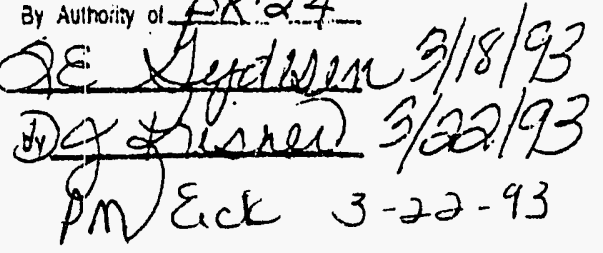

Maintenance

Water Leaks

Process Tubes Replaced

0

OPERATING EXPERIENCE

Power Level

The power level at $K E$ Reactor was restricted by orittle fracture tube power limits during the month.

EQUIP!IEIT EXPERIENCE

Vertical and Forizontal Rods

All FCRs continue to be operable with no major binding problems. All VSRs are serviceable with an average hot drop time of 1.77 seconds.
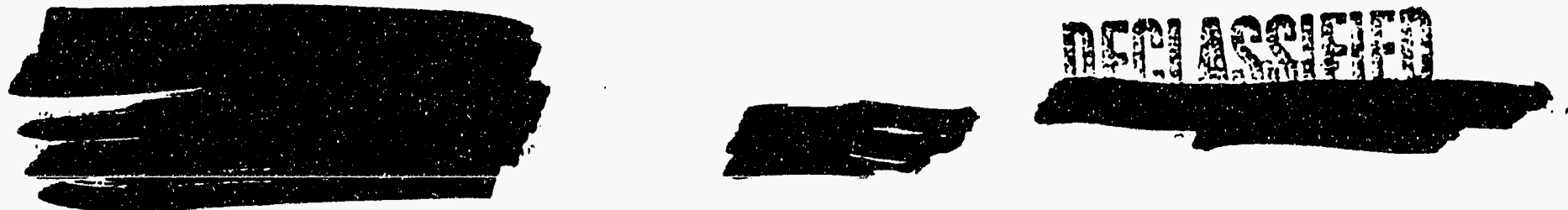


\section{Resistance Temperature Detectors}

Five RTDs were repaired during the October 11 outage. Four of these were found to be slow in response during the monthly EMS checiss.

On-reactor testing of prototype PrDs is continuing under Production Test Authorization 217. There nas been no change in the satisfactory performance of the three developmental strap-on RMDs installed in July, 1970. Ten additional developmental strap-on RTDs were installed. on the is Reactor during this report period.

184-DA Boiler

The 184-DA packaged boiler received a third party inspection following a complete retubing by the J. A. Jones Company. The boiler was returned to normal service on October 7 .

Rear Crossineaders - KE Reactor

Recent inspections revealed several potential leaks caused by stress corrosion. One leak was repaired with a silastic material and a saddle clamp. Twelve suspect areas on eleven headers were identified by salt deposits, one of which was confirmed when the deposits were removed. A complete inspection wili be made during the next outage, and the $\mathrm{KN}$ headers will also be inspected. Based on the findings, $a$ program will be developed.

Pump iisalignment at $182-K$

A pump-to-engine misalignment was found on the No. $I$ unit at $182-K$. The pump side of the coupling was 0.13 inch higher than desired, and there was a 0.06 inch side displacement. The misalignment was caused by expansion of the grout under the pump sole plate. The pump was reset and regrouted with a very dry sand and cement grout, and the grid member in the coupling was replaced.

\section{Ball 3X Channels}

During the October outage, channel no. 67 was inspected and found clear and in good condition. Channel no. 21 was cleared of debris; and when the channel was borescoped, it was found to be clear. 


\section{REACTOR OUTAGES}

Date Dorn

$10 / 11$
Date Up

$10 / 17$ $\underline{\text { Remariss }}$

Scheduled Charge-Discharge

\section{EFFLUEIT ACIVITY - October}

The collant water alum feed rate vas maintained at $13.9 \mathrm{ppm}$. The pH averages 6.71 . The sodium dichromate feed rate was 0.50 .

Concentrations of significant isotopes in the effluent are listed below and, for comparison, the concentration at KE Reactor for the same month in the previous two years. Concentrations are in picocuries per milliliter.

\section{$\underline{P-32} \underline{A s-76} \quad \underline{N p-239} \quad \underline{C r-51} \quad \underline{\text { Sc-46 }} \quad \underline{\mathrm{n}-65} \quad$ (September)}

$\begin{array}{lllllll}1970 & 1.6 & 49 & 69 & 93 & 9.2 & 4.4\end{array}$

$\begin{array}{rrrrrrr}68 * & 85 * & 6.8 * \\ 1969 & 6.0 & 91 & 41 & 83 & 7.6 & * * \\ 1968 & 6.8 & 95 & 104 & 108 & * * & 7.9\end{array}$

* September data not reported last month due to key punch error on data card.

**No measurements.

RESEARCH AND DEVELOPMENT

\section{$\underline{K}$ Zircaloy Tubes}

Tube 3058, removed as a leaker in September, is being examined. Tris tube was one of five treated in PT-204 in February by both anodic stripping and etching to remove surface hydrides. The leak resulted from a crack in the Van Stone flange. This area was masked during the cleaning operation and was not in contact with either of the electrolytes, and therefore the hydride rernoval production test is not considered to ve in any way related.

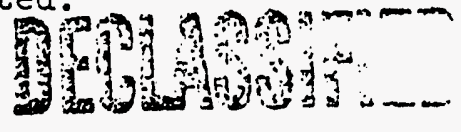




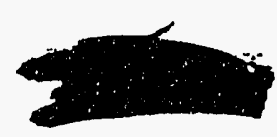

Files

$-4-$

iTovember 16, 1970

$\underline{K}$ Water Chemistry

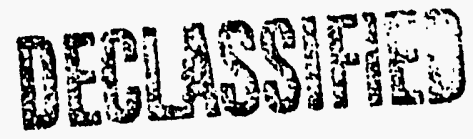

The final report of Production Test 176 was issued as DUN-7253,

"Half-Plant Low Dichromate Evaluation at KW Reactor - Final Report". The objectives of the test were (1) to compare the ability of 0.5 and $1.0 \mathrm{ppm}$ sodium dicluromate to inhibit localized corrosion of aluminum fuel element cladding in the $K$ Peactors, and (2) to define temperature and exposure effects on cladding corrosion at the tiro diciromate additions. The first objective was fulfilied. Equations vere developed to descrive and predict fuel claciding uniform corrosion rates at both dichromate concentrations and the ef sect of dichromate concentration on localized corrosion vas clearly established.

As a result of the test, the Process Standards are veing revised to standardize operation at $\mathrm{KE}$ Reactor with $0.5 \mathrm{pjm}$ dichromate for periods when surface temperatures are below $.220^{\circ} \mathrm{C}$ to talse advantage of the decreased costs of operation with low diciromate. A modest increase in coolant pH during the low temperature months is also being studied to effect further operation economies.

OR:JPS :RBS
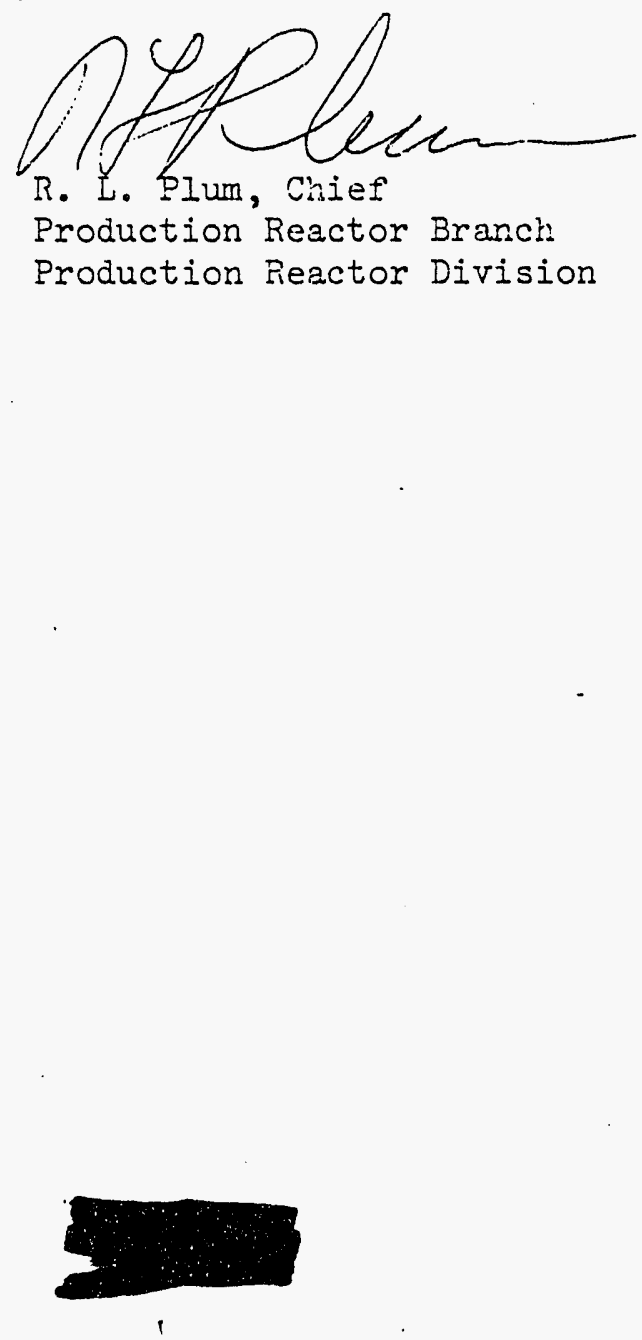

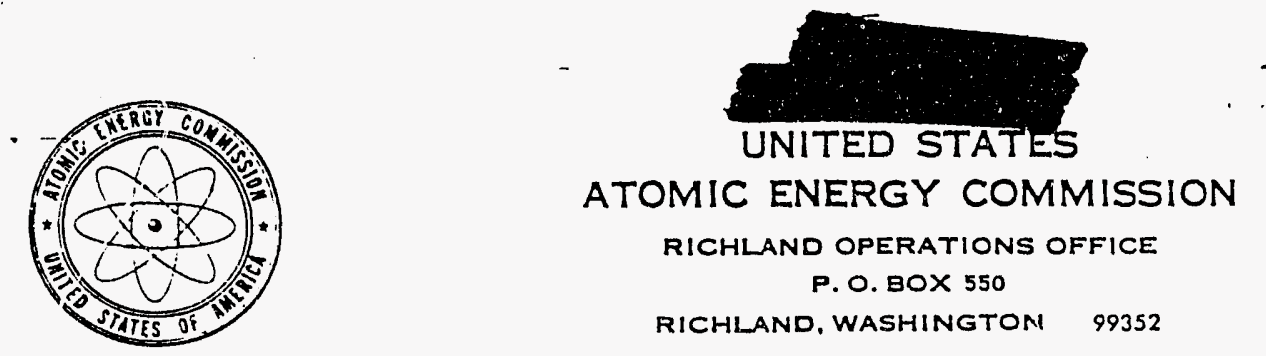

PRD-102 9

\author{
HANFORD CMTEOOY $\div-1,2$ \\ October 9, 1970
}

Files

MONTHLY REPORT FOR SEPTEMBER 1970

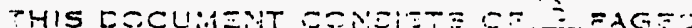

SUMMARY

The reactor remained down until September 4 due to abnormally figh Columbia River temperatures. Equilibrium power level was restricted to $3750 \mathrm{KW}$ by brittle fracture tube power limits.

REACTOR OPERATIONS AND MAINTENANCE

Operation

Input KMWD

\% of Forecast

T.O.E.

Operational Limitation

Ruptures

Maintenance

Water leaks

Process tubes replaced
IEE

83

100

78.6

Tube Power

0

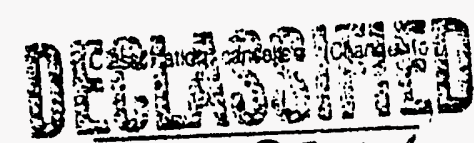

By Autresicy ci $P R-24$

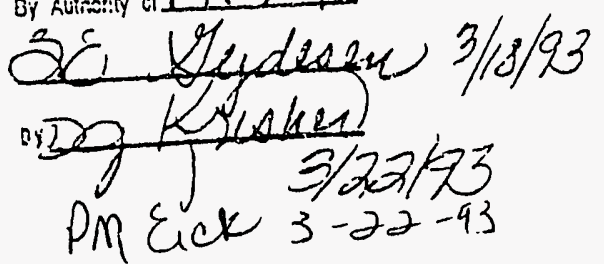

$I$

1

One zirc process tube was replaced because of a leaking Van Stone flange.

\title{
OPERATING EXPERIENCE
}

Power Level

The power level at KE Reactor was restricted by brittle fracture tube power limits during the month.

\section{Replacement Electric Energy}

About $52 \mathrm{MW}$ of replacement power has been used at $\mathrm{KE}$ since the September 4 startup due to termination of interruptible power by BPA.
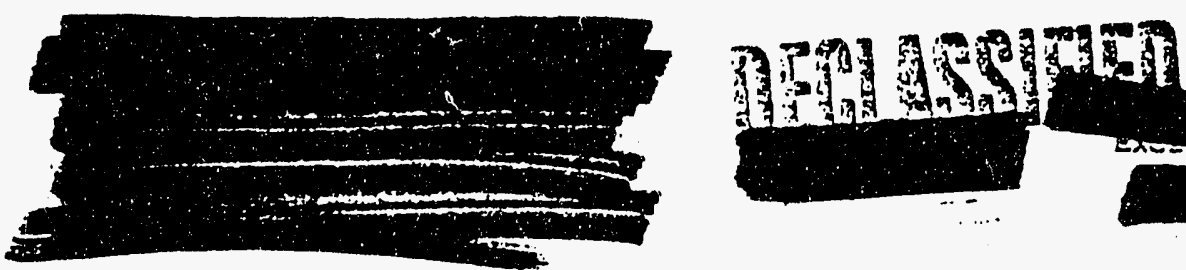
The cost of the replacement power has been 3.5 to $4.5 \mathrm{mills} / \mathrm{kwh}$ on an energy basis, as compared with interruptible power at $2.5 \mathrm{mills} / \mathrm{kwh}$ on a demand basis.

\section{Columbia River Temperatures}

Startup from the August 14 outage was delayed by abnormally high Columbia River temperatures. The maximum observed daily temperature was $20.4^{\circ} \mathrm{C}$ on August $31,20.3^{\circ} \mathrm{C}$ on September $1,19.8^{\circ} \mathrm{C}$ on September 2 , and $19.2^{\circ} \mathrm{C}$ on September 3 . Reactor operation with river temperatures above about $19.5^{\circ} \mathrm{C}$ would have violated the Washington State water quality standards.

\section{EQUTPMENT EXPERIENCE}

Vertical and Horizontal Rods

All HCRs continue to be operable with no major binding problems. All VSRs were serviceable and the average hot drop time was 1.77 seconds.

Resistance Temperature Detectors (RTDs)

There were no RTD failures during September.

\section{Panellit Gauges}

Two Panellit scrans were experienced during September. The first scram occurred September 14 on Panellit gauge 5571. No abnormalitiz could be found with the charge makeup, charge position, or hardware integrity. The toggle valve-was found to be leaking when depressed, and leakage at this valve is believed to be the cause of the scram. Eight rows of toggle valves were replaced because of aged o-rings. The second Panellit scram was experienced on September 17 when the drive arm on the 3-A test hole Panellit gauge became disengaged. Operation resumed when the arm was replaced.

\section{4-D Boiler}

J. A. Jones Company has completed retubing the 184-DA boiler. This is a package boiler that supplies building heat and steam to the thermal hydraulics laboratory. It is expected to be placed into service during the week of October 5 .

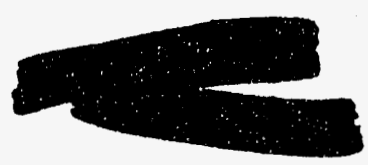


REACTOR OUTAGES

\begin{tabular}{lll} 
Date & Date & Outage \\
Down & Up & Hours \\
\hline
\end{tabular}

$8 / 14 \quad 9 / 4 \quad 86.0$

$\underline{\text { Remarks }}$

Charge-discharge, termination of interruptible electrical power and high river temperature.

$9 / 14 \quad 9 / 16 \quad 67.6$

Panellit trip.

$9 / 17$

$9 / 17$

0.5

Faulty Panellit on 3-A test hole.

\section{EFFLUENT ACTIVITY - September}

The collant water alum feed rate was maintained at $13.2 \mathrm{ppm}$. The $\mathrm{pH}$ averaged 6.70 . The sodium dichromate feed rate was $0.50 \mathrm{ppm}$.

Concentrations of significant isotopes in the effluent are listed below and, for comparison, the concentration at KE Reactor for the same month in the previous two years. Concentrations are in picocuries per milliliter.

\begin{tabular}{|c|c|c|c|c|c|c|}
\hline & $\underline{P-32}$ & $A s-76$ & Np-239 & Cr-5I & $s c-46$ & $\underline{\mathrm{Zn}-65}$ \\
\hline 1970 & 1.1 & 55 & * & * & * & 5.1 \\
\hline 1969 & 6.1 & 98 & 66 & 95 & 5.1 & 13.2 \\
\hline 1968 & 7.3 & 47 & 84 & 81 & ** & 15.9 \\
\hline
\end{tabular}

* Data not available at report time due to key punch error on data card.

**Yo measurements

RESEARCH AND DEVELOPMENT

No significant events.

OR: JPS : RBS

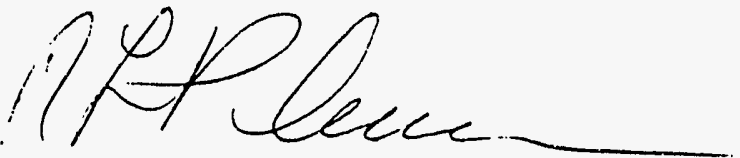

R. L. Plum, Chief

Production Reactor Branch

Production Reactor Division

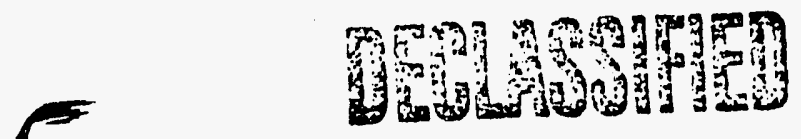




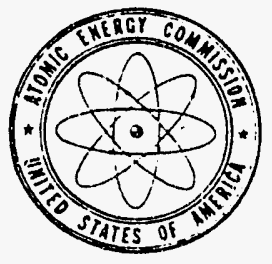

\section{UNITED STATES}

ATOMIC ENERGY COMMISSION

RICHLAND OPERATIONS OFFICE

P. O. BOX 550

RICHLAND, WASHINGTON 99352

PRD-102 8

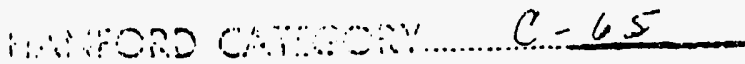

September 11, 1970

THIS DOCUMENT ECNBIETS OF 5FAGES

Files

NONTHLY REPORT FOR AUGUST 1970

SUIMARY

Equilibrium power level was restricted to 3865 MW by brittle fracture tube limits.

REACTOR OPERATIONS AND MAINTENANCE

Operation

$\underline{\mathrm{EE}}$

Input KNWD

48.8

\%t of Forecast

57.2

T.O.E.

43.2

Operational limitation

T.P.L.

Ruptures
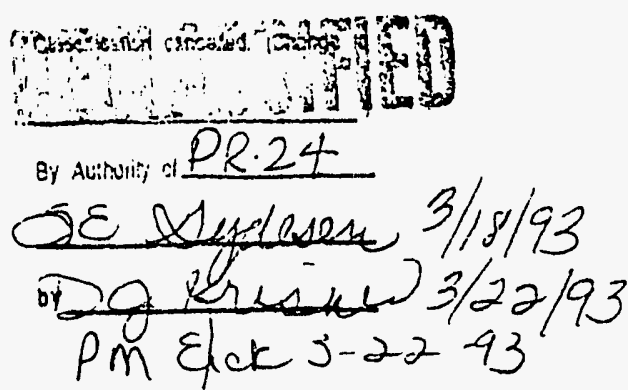

Maintenance

Water leaks

Process Tubes Replaced

OPERATING EXPERIENCE

The reactor was shut down on August 14 due to a shortage of interruptible power from BPA. Interruptible power was made available at 12:01 a.m. August 31 , but reactor startup was delayed due to unusually high Columbia River temperatures, i.e., in excess of $19.5^{\circ} \mathrm{C}$.

The first week of the outage was utilized doing scheduled charge-discharge activities. The second week was utilized with miscellaneous maintenance.

$(\because: 0,1: 0$
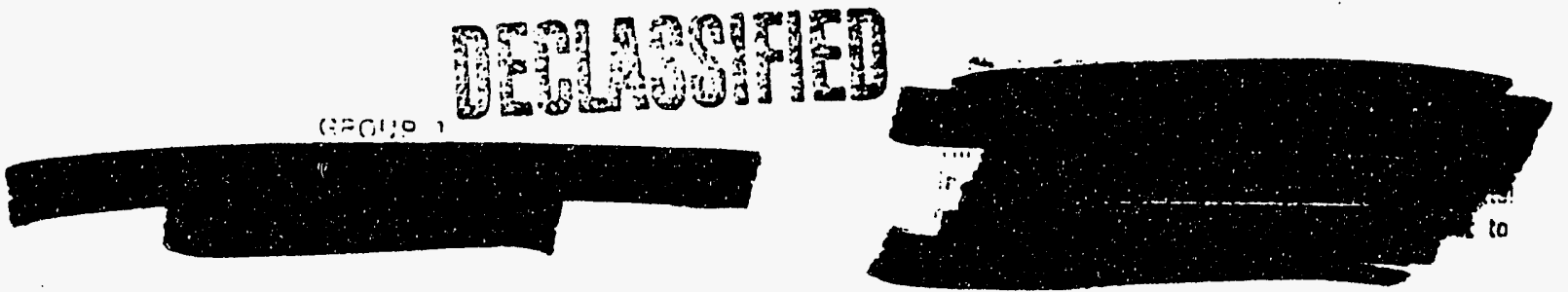
EQUIPMENT EXPERIENCE

Resistance Temperature Detectors (RTDs)

Eight RTDs were replaced during August. Eighty-six RTDs have failed since the internal rear hardware decontamination was performed in February.

Dead Fanellit Gauges

The water flow from the front face to the Panellit manifold was checked on all Panellit lines. Twenty-nine lines were found to have low flow and have been unplugged. The fittings of all Panellit gauges were checked as to the type of fittings. All but 21 fittings were of stainless steel. These 21 were of galvanized metal and were subsequently replaced.

Graphite Stringer Replacement

Graphite stringer 5385 was replaced because sufficient thermocouples had failed to render the stringer inoperable.

Panellit System Leaks

The Panellit system was pressure tested to 350 psig. Thirteen leaks were found and were repaired.

\section{REACTOR OUTAGES}

Date Date Outage

Down Up Hours

$\underline{\text { Remarks }}$

8/14 Still down Reactor shut down due to BPA power condition.

\section{PLANT LIFE}

\section{K Graphite Distortion Measurements}

Additional vertical traverses from $\mathrm{KE}$ reactor have confirmed turnaround of the KE graphite distortion in the transverse (vertical) orientation. Turnaround occurred at three percent contraction and $7.5 \times 1021$ nvt at $\mathrm{KE}$ reactor, compared with turnaround at $\mathrm{KW}$ at 2.5 vercent and $7.0 \times 1021$ nvt (reported previously). 


\section{K Brittle Fracture}

The $K$ reactor inlet supply piping system water hammer studies have been completed. The results of these studies are (1) that peak pressures due to 24-inch check valve closure following the postulated failure of a single riser would be below normal operating pressures.

\section{OPERATIONAL SUPPORT PROGRAI:I}

\section{Ten-Kilogram PuAl Irradiation - KE Reactor}

The last of the thoria and supporting enrichment charged for flux tailoring purposes for the 220-tube PuAl block in KE reactor was discharged in August. The remaining enrichment columns near the test block provide normal spiking requirements for the natural uranium loading. The reactivity and heat generation properties of the PuAl columns have now decreased to approximately those of natural uranium, and the 12 remaining PuAl columns will eventually require supporting enrichment.

\section{Americium Irradiation - KE Reactor}

The americium targets charged in May 1969 in KE reactor were discharged during the month. The targets had been spaced within the column to provide variea exposures.

\section{Columbia River Program}

Columbia River temperatures recorded at the Priest Rapids gauging station have been closely monitored during the current warm weather season. River temperatures at Priest Rapids have tended to be distinctly higher during July and August this year than normal. The higher temperatures recorded this year are attributed to the generally warmer ambient temperatures during July and August and below average river flows during this period. The maximum instantaneous temperature recorded at Priest Rapids reached $19.5 \mathrm{C}$ on July 19 and again on August 16.

\section{SPECIAL IRRADIATIONS PROGRAM}

Sixty-five quickie activation analysis capsules were irradiated in the KE quickie facilities for BNT, WADCO, and the University of Washington.

A (U-Pu)O fuel development capsule was irradiated in the KE reactor snout facility for WADCO in support of the LiMFBR Program.

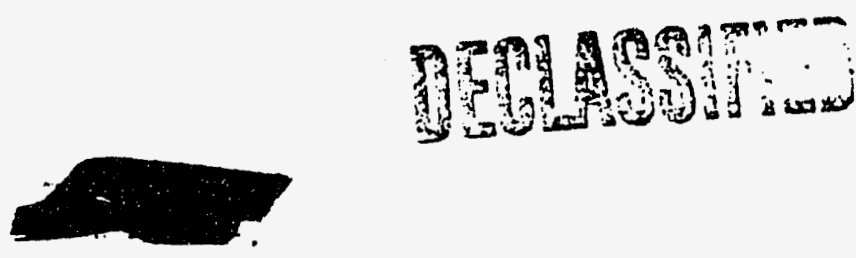




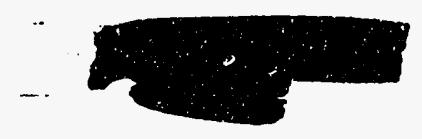

Files

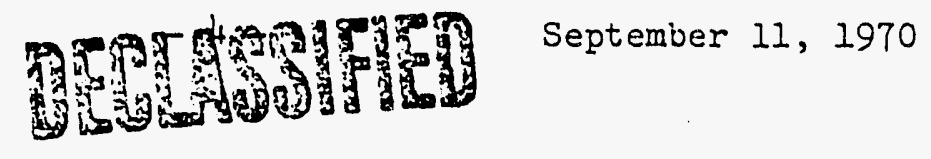

Two casks containing $149 \mathrm{Be}_{3} \mathrm{~N}_{2}$ and ten $\mathrm{KCl}$ targets were sipiped to ORNL for the extraction of $\mathrm{C}-14, \mathrm{~S}-35$, and $\mathrm{Cl}-36$ isotopes.

The third in-reactor KAPL CPTF test was charged, irradiated, discharged, and delivered to BNW Radiometallurgy Laboratory.

\section{EFFIUENT ACTIVITY}

The coolant water alum feed rate was maintained at $11.4 \mathrm{ppm}$. The pH averaged 6.72 . The sodium dichromate feed rate was 0.58 .

Concentrations of significant isotopes in the effluent are listed below and, for comparison, the concentration at $K E$ reactor for the same month in the previous two years. Concentrations are in picocuries per milliliter.

\section{$\underline{P-32} \underline{A s-76} \quad \underline{N p-239} \quad \underline{\mathrm{Cr}-51} \quad \underline{\mathrm{Sc}-46} \quad \underline{\mathrm{Zn}-65}$ (July)}

$\begin{array}{rrrrrrr}1970 & 1.0 & 21 & * & 86 & 4.3 & 4.3 \\ 1969 & 7.5 & 74 & 71 & 92 & 7.3 & 12.2 \\ 1968 & 5.8 & 60 & 102 & 116 & * * & 9.8\end{array}$

*No valid measurements for August

**No measurements

OR: JPS : RBS
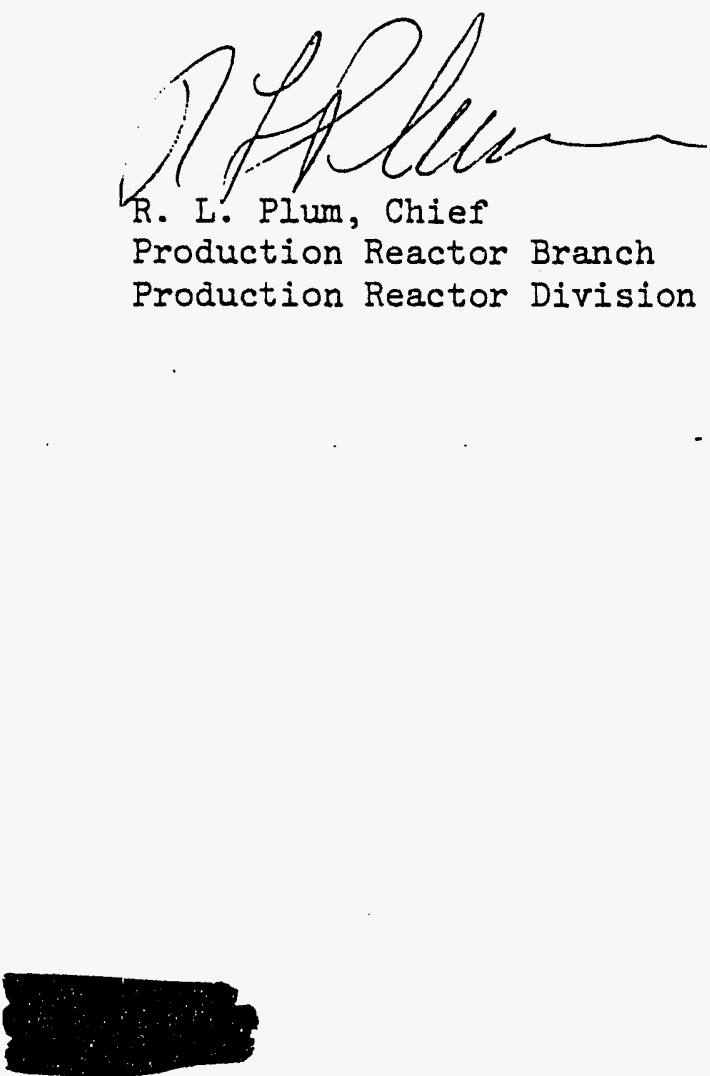


\author{
Reason \\ Charege-Dischoire \\ Tupture Removal \\ Leà ístin \\ Tuive recincenent \\ iaintenance \\ Standand Check \\ Production fests \\ Project iror!s \\ liscellaneous *
}

Total

* Secondary Power outage High river temperature downtime Decontamination of front face
12

148.5

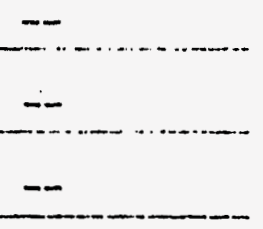

$-20.6$

$-3.5$

$-2.2$

$-=$

241.0

422.6

216.0

24.0

$\frac{1.0}{241.0}$ 


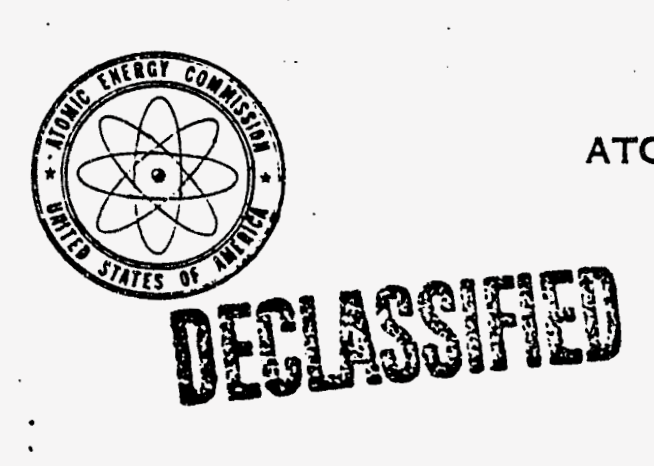
$0=1$
UNITED STATES
ATOMIC ENERGY COMMISSION
RICHLAND OPERATIONS OFFICE
P. O. BOX 550

RICHLAND, WASHINGTON

99352

PRD-I02 7

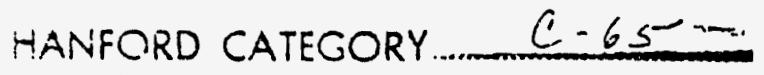

August 12,1970

Files

MONTHLY REPORT FOR JULY 1970

TH:S ZOCUMENT CONGISTS OF 7 FAGES SUMMARY

E3. SERIE

Two irradiated fuel pieces inadvertently buried with expendable dummies were recovered and returned to $\mathrm{kE}$ fuel storage basin.

Columila River temperatures during the month were unusually high, more typical of August river temperatures, normally the period of highest river temperature.

Supplement 6 to the K Reactor Safety Analysis Report on emergency coolant supply was received and forwarded to Headquarters.

REACTOR OPERATIONS AND MAINTENANCE

Operation

Input KMIND

$\%$ of Forecast

T.O.E.

Operational limitation

Ruptures
$K E$

73.1

85.5

68.5

Thube power limited

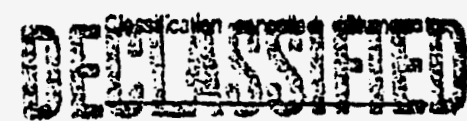

i) sutw:; " 0 . 24

Maintenance

Water leaks

Process tubes replaced

Reactor operation was continued at a reduced power level of 3600 : $\mathbb{W}$ (following the $7 / 26 / 70$ outage) until the normal reactivity increases allowed the establishment of a more favorable rod pattern; the reduced power level assured the reactor was operated witnin the limits established by the brittle fracture tube power memorandum until the desired reactivity was available for rod and spline configurations known to provide good flux distribution control.
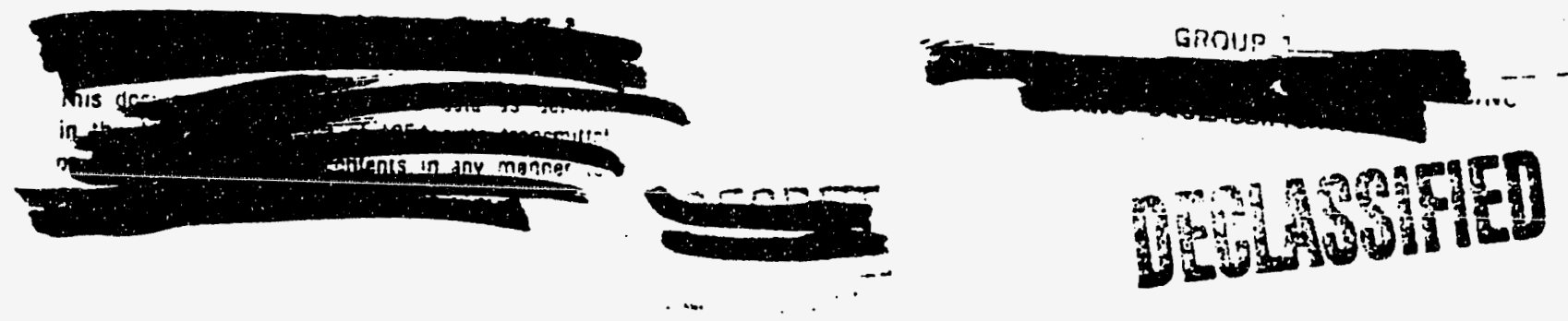


\section{OPERATING EXPERIENCE}

Utilization of Surplus Type $O$ and $C$ Fuel

A total 1,015 C2N green end fuel, 1,735 03N green end fuel, $203 \mathrm{C} 3$ water mixers and 34703 water mixers were utilized in fuel charges. A total of $3,074 \mathrm{C} 2 \mathrm{~N}$ fuel and $11,10403 \mathrm{~N}$ fuel pieces were also utilized in the fuel charges of KE reactor.

\section{EQUIPMENT EXPERIENCE}

Vertical and Horizontal Rods

All VSRs and HCRs are serviceable although the No. 7 HCR indicated binding between zero and ten percent during the July 27 outage, startup.

\section{Resistance Temperature Detectors (RTDs)}

Five RTDs were replaced during July. Seventy-eight RTDs have failed since the internal rear hardware decontamination was performed in February.

Dead Panellit Gauges

Three dead Panellit gauges were found during a routine check of the Panellit system July 30. Two of the dead gauges were the result of plugging at the venturi assembly. The sensing line to the venturi assembly was removed during operation and the plugged area cleared. The other dead gauge was believed faulty. The gauge operation was normal after a new gauge was installed. It is planned to check all Panellit lines for plugging during the next outage.

Cold Boiler Startup - $165 \mathrm{KW}$

The renovated $750 \mathrm{kw}$ diesel generator was delivered on July 30. Target date for completion of this work is October 1, 1970.

Irradiated Fuel in No. 2 Dummy Silo

Two pieces of irradiated natural metal were inadvertently included in a cask of dummies being transferred to the No. 2 dummy silo in the burial ground on July 16. Coolant was applied to the elements until removal could be completed on July 30 . Recovery efforts were started on July 27 after the completion of the scheduled outage at KE reactor. There was

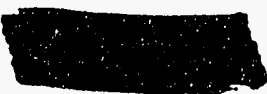




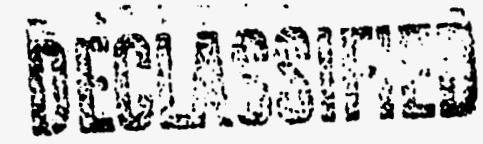

Files

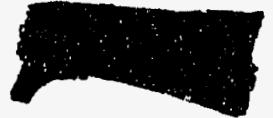

$-3-$
August 12, 1970

no release of radioactive material, and no employee received radiation exposures above planned limits during the entire operation. The two irradiated elements have been returned to the 105-KE storage basin.

Transfer Area Crane; 105-KE

Two incidents occurred with the crane. Both times the load appears to have been picked up on the point of one hook. In the first case, the cask slipped onto the hook which reversed the movement on the hook and threw the cable off one equalizer sheave. This reversed the movement a second time and, when the cask slack was gone, the shock rotated the hook between the side plates shearing all four hook retention studs. The hook did not detach from the sheave block and the cask only fell a few inches.

The second incident was similar except the cask slipped from the point of the hook completely off. The spring in the cables lifted the hook block into the air and slackea the cables which then came off both equalizer sheaves. The hook block and cable fell on top of the cask in the well car with the equalizer end of the cable falling across the center platform. The cask was just starting to lift and only fell a few inches.

Cable retainers have been installed to prevent the cables from getting off the equalizer sheaves. A mirror similar to the one on the KN crane is being installed at $\mathrm{KE}$. This will make it easier for the operator to see the location of the hooks in the cask and help prevent picking a cask up on the hook points.

REACTOR OUTAGES

\begin{tabular}{lccc}
$\begin{array}{c}\text { Date } \\
\text { Down }\end{array}$ & $\begin{array}{l}\text { Date } \\
\text { Up }\end{array}$ & $\begin{array}{c}\text { Outage } \\
\text { Hours }\end{array}$ & \multicolumn{1}{c}{ Remarks } \\
$7 / 9$ & $7 / 11$ & 35.7 & $\begin{array}{l}\text { Broken wire strands on front face con- } \\
\text { nector } \# 3593 .\end{array}$ \\
$7 / 19$ & $7 / 25$ & 163.7 & $\begin{array}{l}\text { Scheduled charge-discharge and miscellaneous } \\
\text { maintenance. }\end{array}$ \\
$7 / 27$ & $7 / 29$ & 32.0 & Trip on pressure monitor.
\end{tabular}

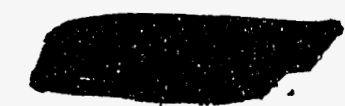




\section{PROCESS TECHNOLOGY}

K Reactor Process Tubes

Sixty-six aluminum process tubes in the $K E$ reactor were probologged to determine their current wall thichness as a guide for tube replacement. The majority of the tubes examined had been in service since 1955. OnIy two tubes measured less than 50 mils wall thickness. The minimum wall thickness measured was $44 \mathrm{mils}$ in tube 0353, which is believed to be due to a period of accelerated corrosion resulting from misaligned fuel.

\section{RESEARCH AND DEVELOPMENT}

\section{Operational Support}

\section{Columbia River Temperatures}

Columbia River temperatures, as measured and recorded at the Priest Rapids gauging station which is upstream of the Hanford site, are currently running much higher than normal. Temperatures are currently exceeding the temperatures which would normally be expected during August, which is historically the period of highest river temperatures. These high temperatures are attributed to extremely high ambient temperatures for the past several weeks in conjuncticn with lower than normal river flows. The maximum daily average temperature at Priest Rapids was $19.2^{\circ} \mathrm{C}$, on July 19.

Ten Kilogram PuAl Irradiation - KE Reactor

One of the PuAl monitor columns was discharged, and some of the thoria and 94 metal was replaced with natural uranium. Of the approximately 200 original thoria and 94 metal columns in the block, only 11 thoria and less than 60 of the 94 metal columns remain. A study was made to assess the rupture potential of the 11 remaining thoria columns in the PuAl test block, which indicated that those columns could feasibly be expected to operate three or four times their current exposure without undue rupture risk. Decreasing power and reactivities in PuAl columns are expected to permit the removal of the 11 thoria and the suppurting 94 metal columns later this summer.

Nuclear Safety Assurance Program

Safety Analysis Report - Emergency Coolant System

Supplement 6 to the $K$ Reactor Hazards Summary Report was received and forwarded to $\mathrm{HQ}$ for information. The deactivation of $\mathrm{kW}$ reactor required

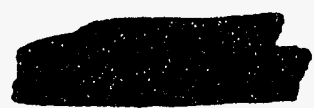




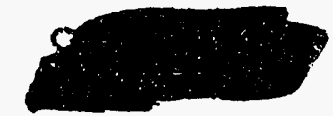

$-5-$
August 12,1970

that modifications be made in the last-ditch cooling system at $K E$ reactor to comply with the continuity of coolant criterion. The original system depended upon a continuous water supply from the $K E$ and $K W$ clearwells, and the system as now modified will be supplied by stored water from the $K E$ sedimentation basin and the $K E$ and $K W$ clearwells. This will provide a seven-day water supply, and procedures have been developed whereby alternate sources of power for the KI river pumps can be made available during the seven days that the reactor is dependent upon stored water.

Special Irradiations Program

Isotope Production

Chlorine-36 and Sulfur-35 Production - Oak Ridge National Laboratory

Ten capsules containing potassium chloride were discharged from the $\mathrm{KE}$ reactor magazine facility. This material will provide $\mathrm{Cl}-36$ and S-35 for ORNL's Radioisotope Distribution program.

Materials Testing

Corrosion Product Transport Studies - Battelle Nortinest Laboratory

The second in-reactor test at $K E$ reactor was completed, and the test section was discharged and delivered to BNW's Radiometallurgy Laboratory for examination. The third in-reactor test will begin in July.

Fuel Development

LIFBR Fuel Development - WADCO

The first in a series of ceramic fuel swelling capsules was irradiated in the $K E$ reactor snout facility. This short-term irradiation was for the purpose of confirming calculated heat generation and transfer values.

A mixed oxide fuel creep capsule was irradiated in the $K E$ snout facility for WADCO.

A creep rate capsule was discharged from the outlet end of the $2 \mathrm{~A}$ general purpose facility after the 316 stainless steel specimen had failed.

Rouitine Irradiations

Sixty quickie activation analysis capsules were irradiated in the $\mathrm{KE}$ 


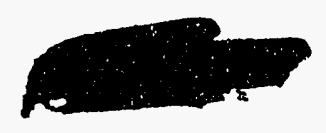

Files

quickie facilities for BNW, WADCO, U. S. Testing, and the University of Washington.

\section{Effluent Activity}

The coolant water alum feed rate was maintained at $18.4 \mathrm{ppm}$. The $\mathrm{pH}$ averaged 6.72 . The sodium dichromate feed rate was 0.50 .

Concentrations of significant isotopes in the effluent are listed below and, for comparison, the concentration for the same month in the previous two years. Concentrations are in picocuries per milliliter.

\begin{tabular}{|c|c|c|c|c|c|c|}
\hline & $p-32$ & As-76 & $\mathrm{Np}-239$ & $\mathrm{Cr}-5 \mathrm{I}$ & $S c-46$ & $\underline{\mathrm{Zn}-65}$ (June) \\
\hline 197 & 1.3 & 30 & 164 & 84 & 6.0 & 12.7 \\
\hline 1969 & 9. & 122 & 83 & 108 & 8.1 & 7.5 \\
\hline 706 & 3.8 & 75 & 113 & 118 & $\because *$ & 8.2 \\
\hline
\end{tabular}

**No measurements

OR:DMS : RBS

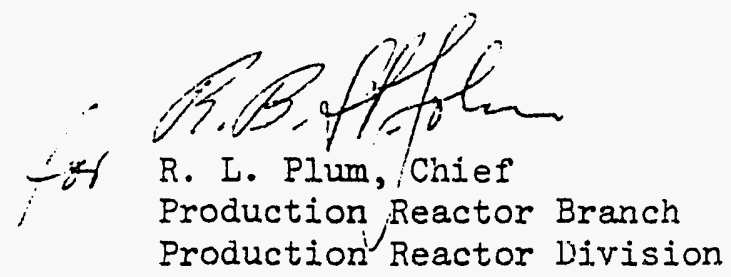




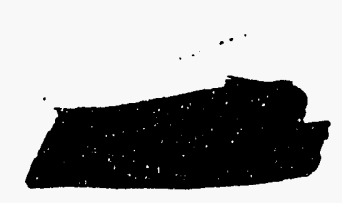

\section{다붕ำ

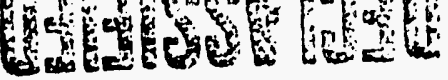

..."

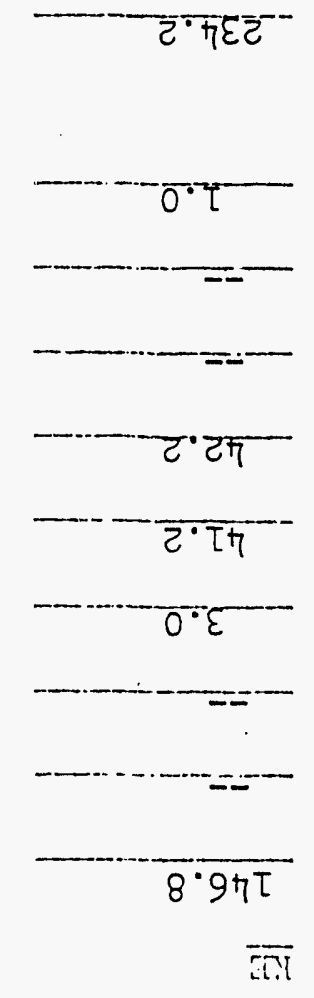

Tอ?ดธ

Snosiistโวอง T:\%

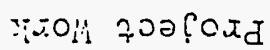

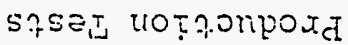

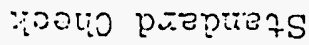

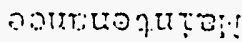

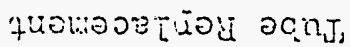

รUTุรอง วอบI

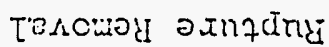

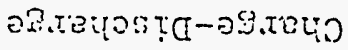

Foseay 


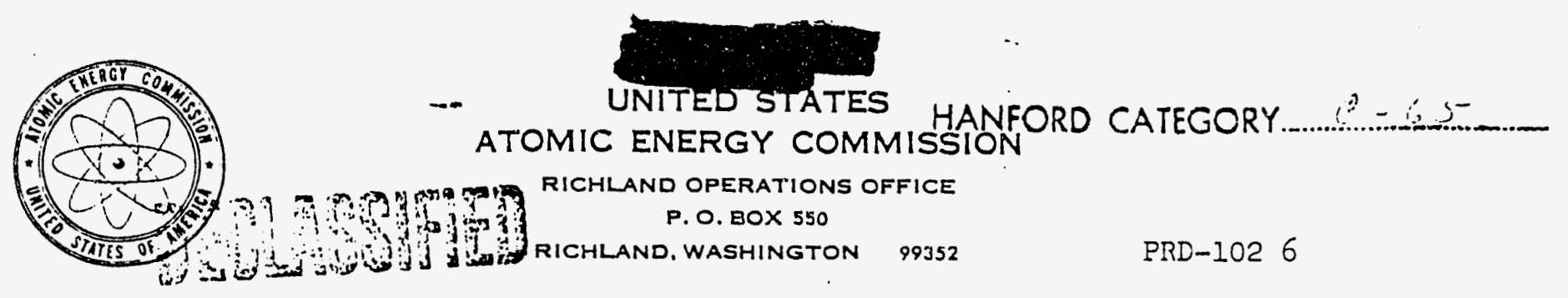

July 20, 1970

Files

WONTHLY REPORT FOR JUNE 1970

SUMMARY

All shield protection thoria was replaced with Li-Al.

The results of the half-plant low dichromate test showed that above $120 \mathrm{C}$ cladding temperature localized corrosion was somewhat more severe in coolant containing $0.5 \mathrm{ppm}$ dichromate vs the normal $1.0 \mathrm{ppm}$ concentration.

A Pu-Al column was discharged at about 30 percent of peak Pu-240 exposure.

REACTOR OPERATIONS AND MAINTENANCE

Operation

Input KIJWD

\% of Forecast

T.O.E.

Operational limitation

Ruptures

Maintenance

Water leaks

Process tubes replaced
$\underline{\mathrm{KE}}$

81.5

88.5

71.9

Tube power limited

I thoria failure

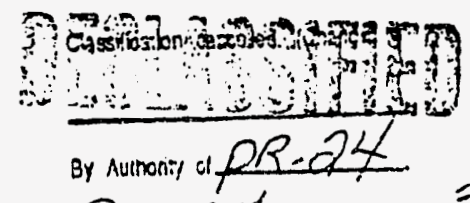

Se $=\frac{2 \% \text { desen }}{3 / 1 \%}$

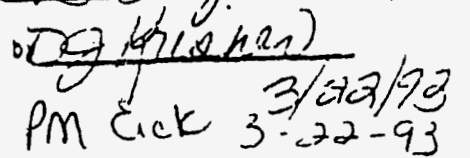

\section{OPERATING EXPERIENCE}

Fuel Failures

A thoria fuel element failed in process tube 0174 on June 2. The previous thoria fuel element failure occurred on November $29,1969$. All shielc thoria tubes were replaced with lithium-aluminum.

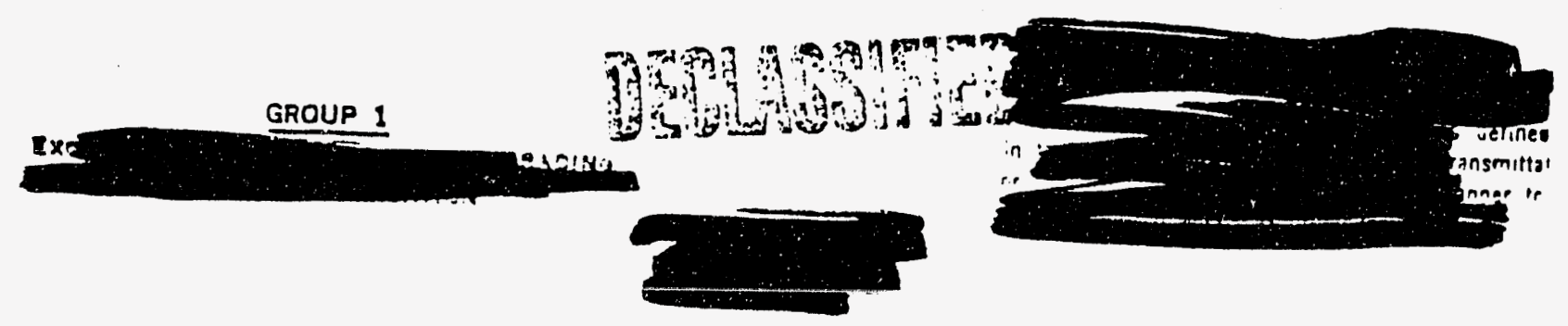




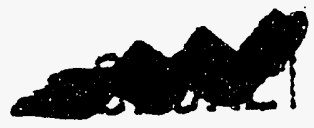

Files

Utilization of Surplus Type 0 and C Fuel

During June 4.2 tons type $Q$ and 2.1 tons of type $C$ surplus fuel were utilized in the fuel charges of $\mathrm{KE}$ reactor. It is planned to use approximately 140 tons of surplus fuel in $\mathrm{NE}$ reactor during the next fiscal year.

EQUIPMENT EXPERIENCE

Vertical and Horizontal Rods

The No. 37 and No. 45 VSRs were replaced with universal flexible rods. Presently, there are 33 universal flexible rods and eight rigid rods in service.

\section{Resistance Temperature Detectors}

Six RTDs were replaced during June. The number of RTD failures since the internal rear hardware decontamination was performed in February is 74 .

\section{Front Face Connector Replacement}

One hundred ninety front face connectors that would not meet EMS requirements were replaced. A waiver has been issued to remove and inspect an additional 500 (estimated) front face connectors as conditions permit.

\section{Boiler Hodifications}

The No. 3 165-KE boiler was returned to service on June 25 following the completion of the exception list items associated with the boiler modification program. No. 2 165-KE boiler has been removed from service to complete similar modifications.

\section{REACTOR OUTAGES}

\begin{tabular}{|c|c|c|c|}
\hline $\begin{array}{l}\text { Date } \\
\text { Down }\end{array}$ & $\begin{array}{l}\text { Date } \\
\text { Up }\end{array}$ & $\begin{array}{l}\text { Outage } \\
\text { Fours }\end{array}$ & Remarks \\
\hline $6 / 2$ & $6 / 4$ & 39.7 & $\begin{array}{l}\text { Thoria rupture on tube } 0174 \text {. Charge- } \\
\text { discharge and misceilaneous maintenance. }\end{array}$ \\
\hline $6 / 24$ & Still & & $\begin{array}{l}\text { Scheduled charge-discharge and miscellaneous } \\
\text { maintenance. }\end{array}$ \\
\hline
\end{tabular}




\section{RESEARCH AND DEVELOPMENT}

\section{Basic Production}

\section{Half-Plant Low Dichromate Evaluation}

Analysis of data from the half-plant low dichromate test in $i$ W reactor comparing 0.5 vs 1.0 pom dichromate was completed. Littie erfect of dicinromate concentration on localized corrosion was observer when fuel cladding temperatures were below $115-120 \mathrm{C}$ but above these temperatures the localized corrosion was definitely more severe in coolant containing 0.5 ppm inibitor. The localized corrosion almost always occurred on the bottoms of the fuel elements, areas of highest operating temperature. The bottom rows of fuel element supports rapidly corroded away at the higher temperatures which caused a further increase in local temperatures due to flow imbalances and this in turn accelerated the localized corrosion. Because the higher dichromate concentration reduced the amount of support corrosion, $1.0 \mathrm{ppm}$ diciromate should be employec to control localized corrosion whenever cladiing temperatures are expected to be above $120 \mathrm{C}$ for long periods of time.

These tests indicated that corrosion occurring at exposures of 66 ( $6 \% \mathrm{Pu}-240)$ operating days, and with clad temperatures of $120 \mathrm{C}$ or above, would not seriously limit fuel integrity at $0.5 \mathrm{ppm}$ inhioitor but that for exposures of 105 ( $9 \% \mathrm{Pu}-240$ ) operating days extensive pitting corrosion would be expected. However, it was found that at the longer exposure periods and higher cladding temperatures operation at $1.0 \mathrm{ppm}$ dichromate would reduce but would not completely eliminate localized corrosion.

\section{Product Flexibility}

Ten Kilogram PuAl Irradiation

A Pu-Al column was discharged at an exposure of about $20,000 \mathrm{iTW} / \mathrm{T}$ (peak Pu-240 is calculated to occur at approximately $28,000 \mathrm{i} / \mathrm{WD} / \mathrm{T}$ ) to provide sample material for evaluating product buildup rates. In addition, six thoria and 29 E-metal columns were replaced with natural metal to compensate for the decreasing PuAl powers, and thus maintain an average tube power of 1000 to $1100 \mathrm{kw}$.

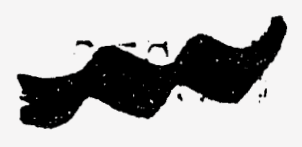


Files

$\begin{array}{lcccccc} & \text { P-32 } & \text { As-76 } & \text { Np-239 } & \text { Cr-51 } & \text { Sc-46 } & \text { Zn-65 (May) } \\ 1970 & 1.5 & 37 & 110 & 94 & 6.7 & 11.2 \\ 1969 & 4.1 & 101 & 101 & 132 & 10.1 & 10.5 \\ 1968 & 4.1 & 63 & 105 & 99 & * * & 12.5\end{array}$

OR: DMS : RBS

$-5-$

July 20, 1970

**No measurements

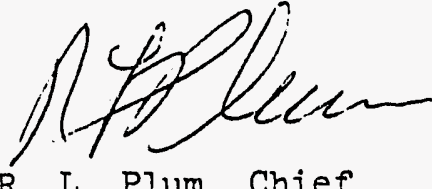

R. L. Plum, Chief

Production Reactor Branch

Production Reactor Division

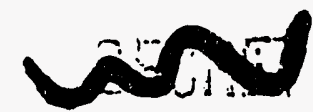




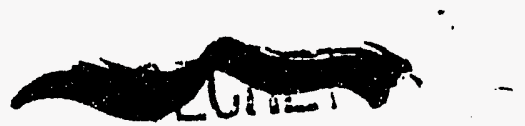

$-6-$

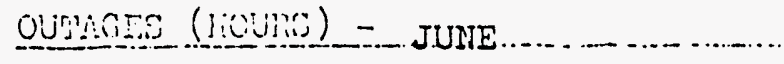

Feason

Chare-Dischare:

Rupture Renova].

Leri: Festini:

Tuide :eolacenent

Haint enance

Stendard Checl:

Production rests

Project Vort:

liscellansous

Totial lili

111,5

$-30.7 \ldots \ldots . . .$.

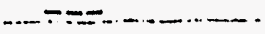

$-2.2$

30.9

12.6

5.8

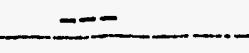

1.5

202.2 


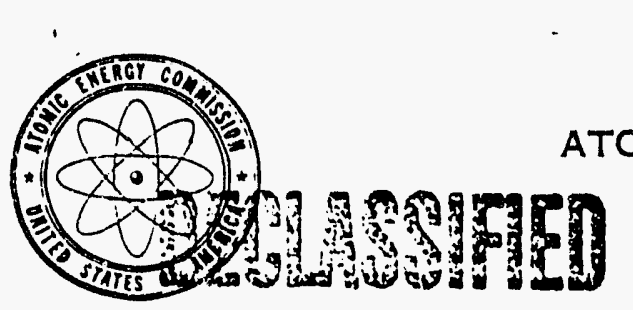

Files

MONTHLY REPORT FOR MAY 1970

SUMMARY

The KE reactor flocculating basins were successfully tied into the last ditch coolant supply system.

Use of nitric acid followed by ammonium fluoride etch has been shown to effectively remove all surface concentrations of hydride in $\mathrm{K}$ process tubes.

The $2 \times 2$ cluster of thin annulus $\mathrm{NpO}_{2}$ targets was charged into $\mathrm{KE}$ reactor starting a three-month irradiation.

REACTOR OPERATION AND MAINTENANCE

Operation

Input KMWD

$\%$ of Forecast

T.O.E.

Operational Limitation

Ruptures

Maintenance

Water Leaks

Process Tubes Replaced

EQUIPMENT EXPERIENCE

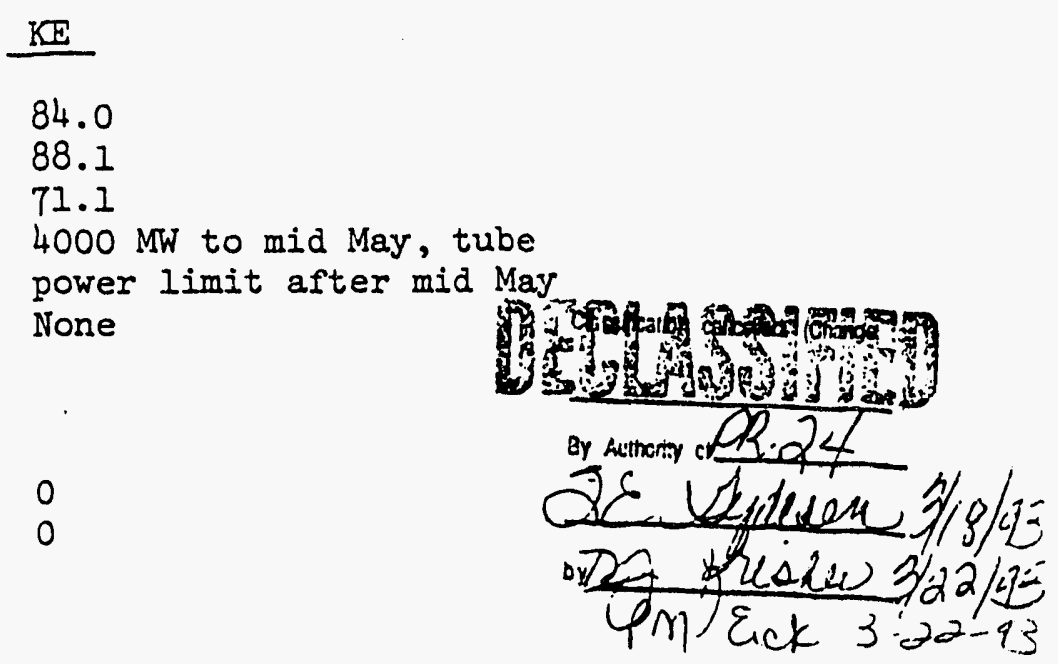

KE

84.0

88.1

71.1 $4000 \mathrm{MW}$ to mid May, tube power limit after mid May None

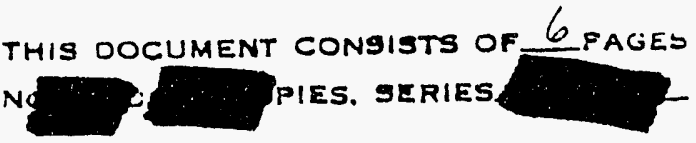

Twenty-seven resistance temperature detectors failed during May for a total of 70 since the chemical decontamination in February.

GROUP 1

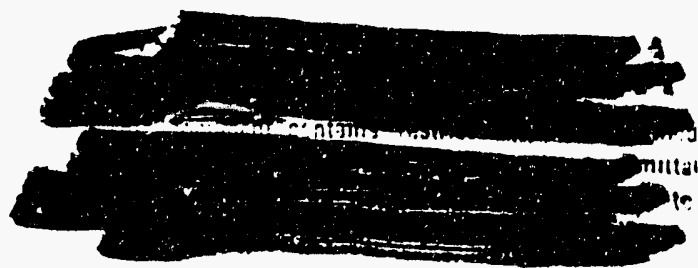

कing

ind 


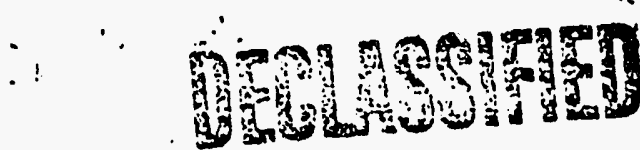

Files

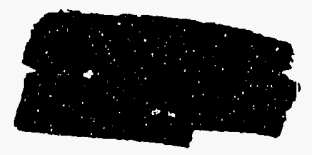

$-2-$
June 16,1970

The tie line between the I83-KE flocculating basins and the filter effluent flume was installed and accepted. This change makes the flocculating basin water storage capacity available to the last-ditch diesel emergency pumps for a seven-day supply of shutdown flow without replenishmeat from the river.

\section{REACTOR OUTAGES}

\begin{tabular}{|c|c|c|}
\hline $\begin{array}{l}\text { Date } \\
\text { Down } \\
\end{array}$ & $\begin{array}{l}\text { Date } \\
\text { Up }\end{array}$ & $\begin{array}{l}\text { Outage } \\
\text { Hours }\end{array}$ \\
\hline $5 / 9$ & $5 / 17$ & 180.8 \\
\hline $5 / 18$ & $5 / 19$ & 30.0 \\
\hline
\end{tabular}

\section{Remarks}

Scheduled charge-discharge and miscellaneous maintenance.

$5 / 19$

Panellit trip on gauge 3077. Miscellaneous maintenance.

\section{RESEARCH AND DEVELOPMENT}

Basic Production

\section{Zircaloy Prucess Tube Hydriding}

\section{Coupon Irradiations}

Zircaloy coupons irradiated for 14 months in KW reactor were analyzed for hydride mechanisms and after effects of electrolytic case layer removal. The following observations appear to be supported by the data:

a. All coupons hydride readily in bare aluminum holders.

b. Hydriding is substantially reduced, but not completely eliminated in anodized holders when electrical contact is maintained between holder and coupon.

c. The only coupons in stainless steel holders which showed a definite increase in base metal content were those which had been laboratory prehydrided.

d. The scatter in the data on base metal hydrogen content of coupons made from hydrided reactor tubes was so great that it will be difficult to draw firm conclusions as to whether hydrogen migration from the case layers occurred. 
Files

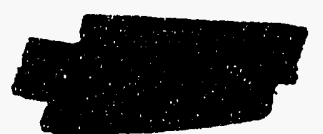

$-3-$

June 16,1970

Hydride Removal Test Results

The final examination of the two KE zircaloy process tubes (2255 and 3056) that had been subjected to electrolytic hydride removal was completed with the following results:

a. Examination of tube 2255 which was anodically treated in three percent nitric acid while in $K E$ reactor showed essentially complete removal of the massive hydride case layer. A layer of dispersed hydride platelets up to 2 mils thick was left on the surface. Only two minor spots of localized corrosion were observed. One of these could not be related to the stripping process.

b. The examination of tube 3056 which had been treated in ammonium fluoride following the three percent nitric acid treatment showed that the combined processes effectively removed all surface concentrations of hydride even though this tube had as much as 19 mils of case layer. A very uneven surface was left in the top of the downstream three feet of tubing which presumably represents a similarly nonuniform hydride layer in the tube before stripping.

\section{Product Flexibility}

\section{Pu-238 Studies}

A $2 \times 2$ column cluster of $\mathrm{NpO}_{2}$ thin annulus target elements was charged into KE reactor on May 10 , surrounded by ten columns of support enrichment. The irradiation period will be about three months. Ten of the $\mathrm{NpO}_{2}-$ aluminum matrix targets contain a mechanically separable, extruded graphite core, and the other ten allow water flow through the center of the element. The test will provide information on the conversion efficiencies and Pu-238 buildup rates of the two types of target at higher exposures.

\section{Foam Encapsulation of Air Containing Noble Gas}

During the report period, two tests were performed utilizing the long-lived foam developed in the noble gas confinement studies. In the initial test, krypton gas, tagged with a small quantity of $\mathrm{Kr}-85$, representing the quantity of krypton released in a full fuel melt at the $N$ reactor, was

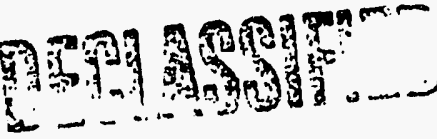




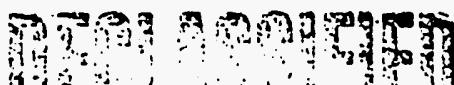

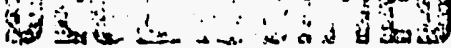

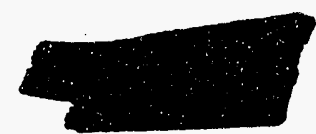

$-4-$

June 16, 1970

introduced to the foam generator, to study krypton gas migration through the foam layers for a period of 15 days. This time period allows 95 percent of fission produced noble gas to decay, leaving only the krypton-85 and some xenon-133. The krypton was seen to move from the lower foam levels to the layers above, but very slowly, at a permeation rate of less than 10 percent per 15-day period through a 10-foot foam layer.

A second test using the same quantities of foam and krypton has been started. The foam generation rate was reduced, thus reducing the expansion ratio to 50 to l, giving a smaller bubble. Preliminary data indicate no migration of krypton and no activity above background in the air space above the foam layer, giving assurance that all air passing through the generator was encapsulated.

\section{IRRADIATION SERVICES}

Isotope Production

Oak Ridge National Laboratory

At ORNL request all ten columns of $\mathrm{Be}_{3} \mathrm{~N}_{2}$ targets were discharged from $K E$ reactor process tubes and test facllities to terminate C-1 4 production.

\section{EFFLUENT ACTIVITY}

The coolant water alum feed rate was maintained at $15.50 \mathrm{ppm}$. The pH averaged 6.67 . The sodium dichromate feed rate was 0.46 .

Concentrations of significant isotopes in the effluent are listed below and, for comparison, the concentration for the same month in the previous two years. Concentrations are in picocuries per milliliter. The isotope measurements in May 1970 compare favorably to prior measurements. The 1969 high As-76 concentration is attributed to unusually dirty river conditions resulting from Grand Coulee Dam drawdown. 
Files

$\begin{array}{llrrrrr} & \text { P-32 } & \text { As-7.6 } & \text { Np-239 } & \text { Cr-51 } & \text { Sc-46 } & \text { Zn-65 (Apri1) } \\ 1970 & 2.6 & 59 & 68 & 74 & 7.4 & 11.7 \\ 1969 & 4.3 & 140 & 92 & 120 & 7.4 & 11.6 \\ 1968 & 7.5 & 55 & 121 & 137 & * * & 12.9\end{array}$

**No measurements

$\mathrm{OR}: \mathrm{DMS}: \mathrm{RBS}$
$-5 \cdots$

June 16, 1970

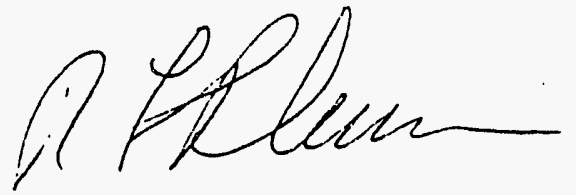

R. L. Plum, Chief

Production Reactor Branch

Production Reactor Division

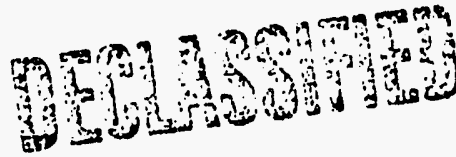


$\infty$

Rezson

- Chorro-Discharo

Rupture Reinova].

Lon: Iostin:

Tuse Replaccilent

jiaintenance

Stanchard Chect:

Production rests

Project ino:

lis iscellencous

T'otal
$\underline{K I}$

120.1

...... - $-\ldots . . . . . . .$.

-... - -

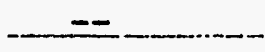

21.0

$-227$

47.0
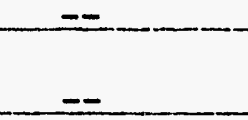

210.8 

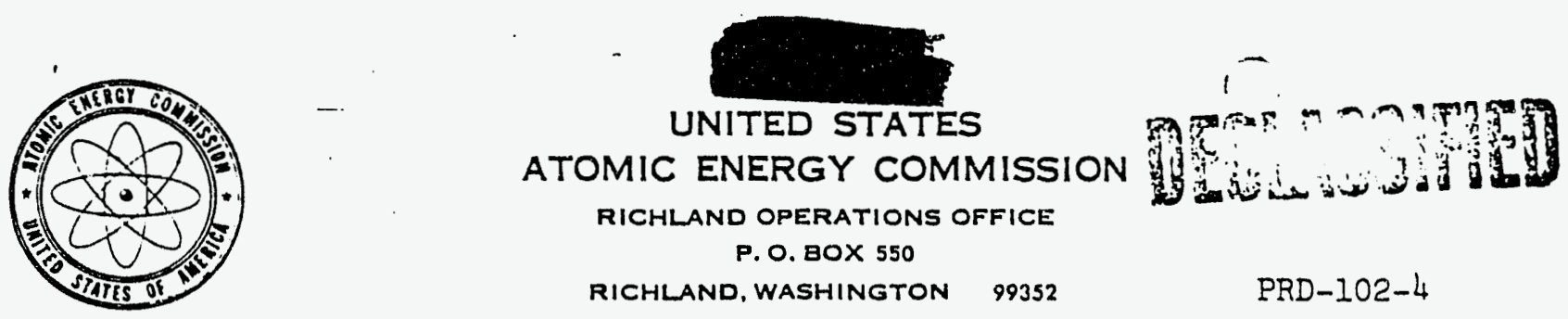

HATIFORD CATEGORY......

Kay 25,1970

Files

:OITTHLY REPORT FOR APRIL 1970

SUR:AIARY

The number of RTD failures due to the February internal rear face hardware decontamination is much less than expected.

Final resolution of the mechanism for ${ }^{46}$ Sc buildup in rear face piping, the source of about 75 percent of the total rear face dose, cannot be made at this time since there is no current budget support for additional research.

Evaluation of the Np-graphite wafers irradiated in Januarr resulted in the finding that the growth rate is sensitive to combined irradiation and fission product damage to the graphite matrix and to the temperature of the wafers.

\section{REACTOR OPERATING AID IAAINTEITANCE EXPERIENYE}

Operations $=$

Input KMND

To of Forecast

TOE

Operational Limitation

Ruptures

Maintenance

Water Leaks

Process Tubes Replaced

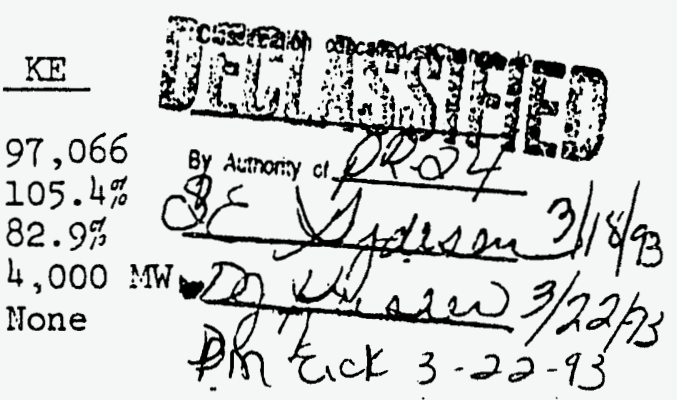

None

None

\section{EQUIP:ENT EXPERIENCE}

Since the internal rear face piping decontamination in February, 59

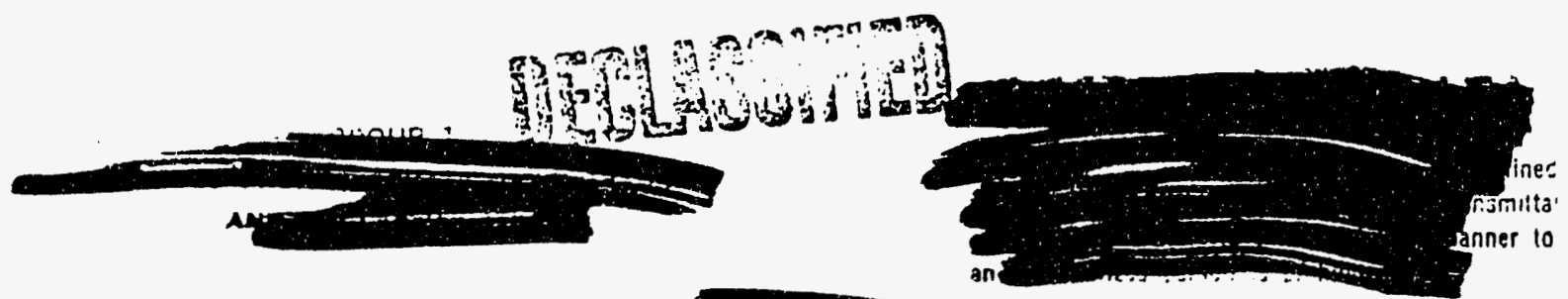


Files

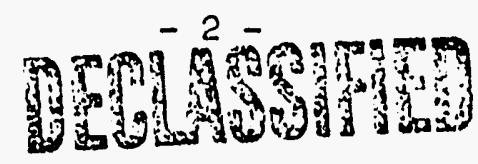

May. 25, 1970

resistance temperature detectors (immersion type) have failed. It had been estimated that the corrosive action of the decontaminant would cause about 200 RTD failures.

REACTOR OUTAGES

Date Date Outage

Down Un Hours

$4 / 5 \quad 4 / 10 \quad 123.0$

Remarlis

Scheduled charge-discharge and miscellaneous maintenance.

RESEARCH AIT DEVELOPIENT

Basic Production

Rear-Face Dose Rate Study

Measurements of relative radioisotopic activities were obtained on a $\mathrm{KE}$ reactor rear-face nozzle which verified previous assumptions that ${ }^{46} \mathrm{Sc}$ now is the major contributor to rear-face dose rates. Because of the inighly energetic, double gamma emissions from ${ }^{46} \mathrm{Sc}$, this one isotope contributes about 75 percent of the total dose rate. Neutron activation analyses of raw Columbia River water during 1969 did not show any:increase in parent scandium in the river. The analyses of filtered water showed that parent concentrations were no higher than in untreated river water; thus, there is no simple explanation for the apparent increased buildup of ${ }^{46} \mathrm{Sc}$ in rear-face piping in recent years. Indications are that either ${ }^{46} \mathrm{Sc}$ is not being removed in the water treatment process as efficiently as it was several years ago or the deposition characteristics have changed in-reactor. Since there is no current budget support for research into this area, further investigation is not planned this fiscal year.

Fuel Examination

The C-reactor fuel examination facility was placed in standby status effective llay 1. Except for rare occasions when the kE-reactor view pit cannot be utilized, there will be no furtiner operation of $C$ basin equipment.

\section{Neptunium Irradiations}

All of the 30 neptunium elements from PTA-163 have been shipped to BiW for dissolution and product recovery. The targets are to be dissolved in tinree batches, permitting separate chemical analysis to be performed on 
each batch. The three batches consist of the $12 \mathrm{NpAl}$ elements irradiated in the core of $\mathrm{KW}$ reactor, the $12 \mathrm{NpGr}$ elements from the core, and the six NpGr elements irradiated in the fringe.

$\mathrm{NpU}_{2}$-graphite wafers were irradiated under PTA-194 to determine the cause of tine excessive longitudinal growth seen in a previous test. Analysis of these wafers shows the apparent cause of growth to be a combination of irradiation and fission product damage to tine graphite matrix. Thermally insulating some of the wafers from the cold cladding caused a marked reduction in the amount of growth.

Ex-reactor flow tests were made on prototype hollow shell (I\&E) neptunium targets. Results of the tests, which utilized flows up to twice the expected in-core flow rates, indicated no evidence of vioration or chattering. Thus, from the thermal-hydraulic standpoint, it will be feasivle to utilize the hollow shell target concept.

\section{PROCESS TECHNOLOGY}

\section{Utilization of $B$ and $C$ Reactor Fuel in KE Reactor}

Thermal-iydraulic studies have been completed to determine the feasibility of fringe and central zone loading of $B$ and $C$ reactor type fuels in $K E$ reactor. Results of the studies indicated that three tvpes of charges could be utilized that would be compatible with the tube power limits currently in application. These charges are as follows:

1. Full-length ( 35 piece) C2N columns charged into central zone aluminum tubes.

2. Mixed $C 2 N-K 4 N$ columns charged into central zone aluminun tubes.

3. Wixed 03N - K4N columns (up to 12 03N pieces in upstream position) . In the outer three lattice units. $\therefore$

Smoke Density Sonitor Installation

Engineering in support of a project to assure compliance with new requirements on air pollution (IAD-0510-13) has been completed. Prototype equipment designed to continuously monitor smoke density of stack emissions was procured and installed on a boiler in 165-KW building and tested. Related design criteria have been developed.

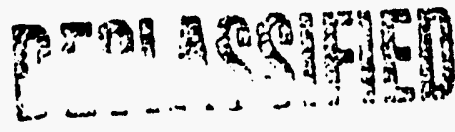


The equipment will be installed on the three boilers in $165-\mathrm{KE}$, three boilers in 184-N, and five boilers in the 300 Area.

The DUN-operated oil-fired boilers are presently operating in accordance with the regulations, and it is expected that periodic tests of stack emissions will be adequate to assure continued compliance with the regulations. Preliminary tests of the four coal-fired coilers in the 300 Area, however, indicate that the quantity of particulate matter in the stack emissions from these boilers may at certain loads be unacceptable. Further testing will be performed before corrective action is recommended.

\section{Procuction Fuel Performance}

There were no production fuel element failures at KE reactor during the report period.

\section{EFFLUENT ACTIVITY}

The coolant water alum feed rate was maintained at $17.25 \mathrm{ppm}$. The pit averaged 6.73 . The sodium dichromate feed rate: was 0.48 .

Concentrations of significant isotopes in the effluent are Iisted below and, for comparison, the concentration for the same month in the previous two years. Concentrations are in picocuries per milliliter. The lower isot ope measurements in April 1970 as ccmpared to measurements in 1968 and 1969 are attributed to the long (seven-week) outage ending Karch 22, 1970.

$$
\underline{P-32} \underline{\text { As-76 }} \underline{\mathrm{ND}-239} \quad \underline{\mathrm{Cr}-51} \quad \underline{\mathrm{Sc}-46} \quad \underline{\mathrm{n}-65} \text { (March }
$$

$\begin{array}{rrrrrrr}1970 & 6.0 & 67 & 48 & 65 & 8.3 & 8.7^{*} \\ 1969 & 9.3 & 1.02 & 61 & 85 & 6.8 & 13.4 \\ 1968 & 18.2 & 119 & 101 & 124 & * * & 15.7\end{array}$

* Nieasurements cover the one veek of reactor operation in ijarch 1970

* Vo measurements. 


\section{IRRADIATION SERVICES}

Xenon-128 Production - Argonne National Laboratories

Two capsules each containing eight pounds of iodine were charged into a downstream position of the KE reactor Snout Facility. This irradiation will yield about $1500 \mathrm{ml}$ of $\mathrm{Xe}-128$ gas from each capsule.

$O R: R L P: R B S$

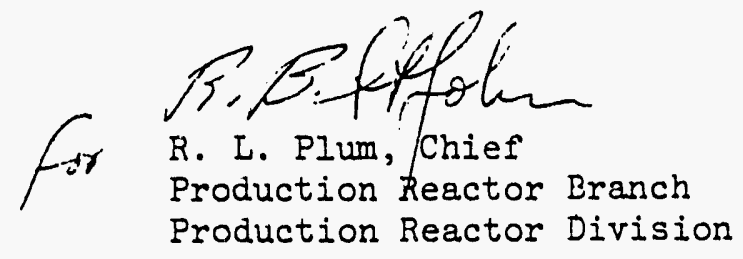




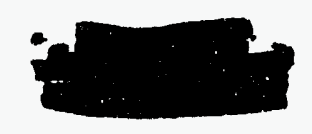

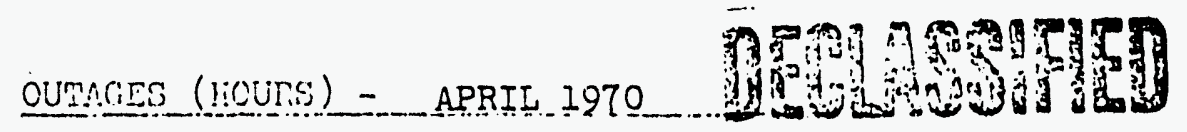

Reason

- Charge-Discharo

Rupture Removal

Les: Festins

Thoe Renicecont

ilaintenance

Stanciard Clucci:

Prociuction 'íests

Project Ho:

liiscollaneous

Total
$\underline{\underline{N}}$

60.7
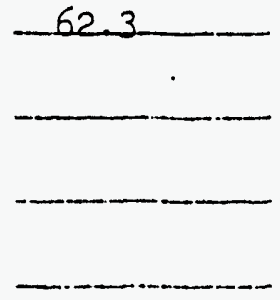

123.0 


\section{$\longrightarrow$ \\ UIITED STATES \\ ATOMIC ENERGY COMMISSION \\ RICHLAND OPERATIONS OFFICE \\ P. O. BOX 550 \\ RICHLAND, WASHINGTON 99352}

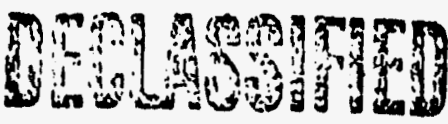

PRD-102 3

HANFORD CATEGORY ........

April 20, 1970

Files

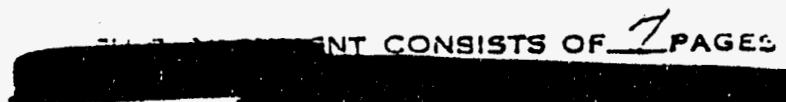

NONTHLY REPORT FOR MARCH 1970

SURMARY

KE reactor was started up Warch 22 following a seven-week outage for replacement of "wye" joints in the inlet piping, pressure testing, and maintenance. The pressure tests were performed successfully.

The charcoal and particulate filters of the confinement system were replaced at $K E$ reactor for the first time. ineasured filtration efficiency after replacement exceeded $99.9 \%$ for both filter types.

Deactivation work at $k \mathrm{~N}$ reactor was 92 percent complete at monti end.

REACTOR OPERATING AND IAAINTENANCE EXPERIENCE

Ooerations

Input Kind

\% of Forecast

TOE

Operational Iimitation

Ruptures

Maintenance

Water Leaks

Van Stone

Internal

Process Tubes Replacea

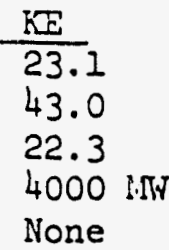

0

1

3

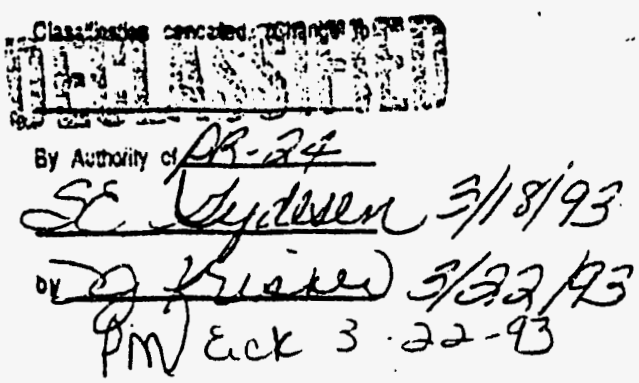

EQUIPI/ENT EXPERIENCE

\section{Zircaloy Tuides}

Two zircaloy tubes were removed from $\mathrm{KE}$ reactor for examination and one because of an internal leak. The leak was confirned by hydrostatic test in reactor but could not be located after tube removal. The leak area may have been obliterated by damage incurred in the removal work.

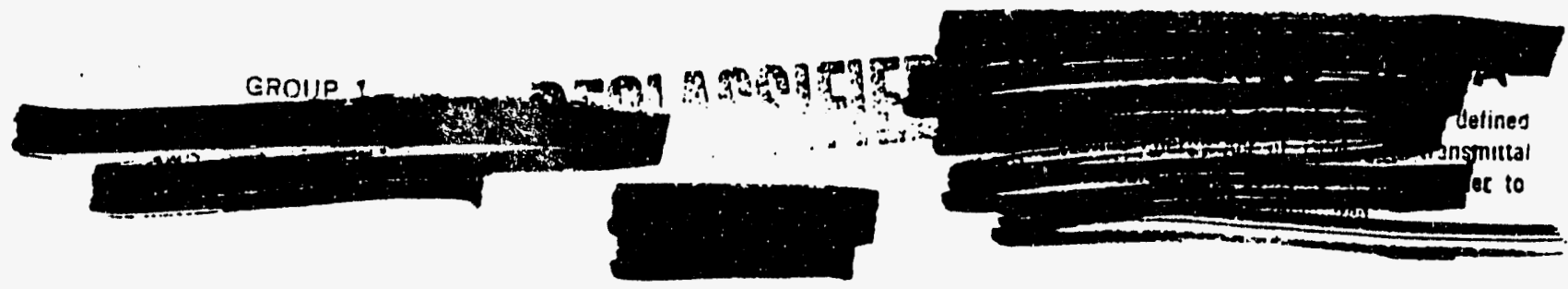




\section{Confinement Filters}

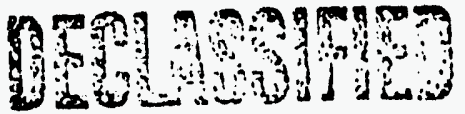

New charcoal filters were installed in $A$ and $B$ cells at KE reactor. $A l l$ tine particulate filters were replaced by filters removed from $C$ reactor. Subsequent tests showed a filtration efficiency of greater than $99.9 \%$ for both halogens and particles.

REACTOR OLTAGES

Date Date Outage

Down Un Hours

$2 / 1 \quad 3 / 22 \quad 980.5$

$3 / 25 \quad 3 / 28 \quad 52.5$
Remarks

Scheduled wye joint repairs, pressure testing, and miscellaneous maintenance.

Reactor shut down for flameout of ino. I boiler caused by ruptured diapinragm in boiler controls.

\section{PROCESS TECHNOLOGY}

There were po production fuel element failures at $\mathrm{KE}$ reactor during the report period.

\section{RESEARCH AND DEVELOPMENT}

\section{Basic Production}

\section{Proof Testing of KE Inlet Piping}

The proof test of the $\mathrm{KE}$ inlet piping was completed at $43-45^{\circ} \mathrm{F}$. Each line from the 24-inch check valves in the 165 building to the top of the riser was successfully pressurized to a top-of-riser pressure of 900 psig. The oressurizer schedule for each line included the fol.lowing:

$$
\begin{aligned}
& 0 \text { to } 400 \text { to } 600 \text { to } 0 \text { psi } \\
& 0 \text { to } 750 \text { to } 400 \text { (for leak inspection) to } 0 \text { psi } \\
& \text { Line flusi to lower water temperature } \\
& 0 \text { to } 900 \text { to } 400 \text { (for leak inspection) to } 0 \text { psi }
\end{aligned}
$$

Strain gauges were installed in the new tee sections, the normal pipe run, the riser, and at a typical riser-to-nozzle connection. Preliminary data indicate that all strains measured were elastic. All defect indications found by ultrasonic inspection prior to the test were reexamined by tine same method after the test and were found to be uncianged. 


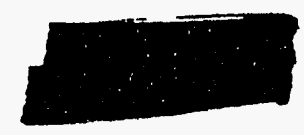

Files

$-3-$

April 20, 1.970

The proof test appears to have been a success in all respects, with no detrimental effects to any of the system components.

Through-Reactor Decontamination

The production test (PTA-158, Supplement B) of through-reactor decontamination with a full crossheader to $\mathrm{KE}$ reactor, employing preneated decontamination solutions, was successfully conpleted on February 19.

A solution of $6 \mathrm{oz} / \mathrm{gal}$ Turco $4528-\mathrm{F}$ (inhibited citric-oxalic acid) preheated to $90 \mathrm{C}$ was injected into the front crossheader and through the process tubes at a flow rate of $1.5 \mathrm{gal} / \mathrm{min} /$ tube for 40 minutes. Due to heat loss to the graphite, exit temperature at the rear face was $78 \mathrm{C}$. Activity measurements on liquid samples periodically removed at the rear face and on continuous recording radiation detectors installed on rear nozzles and crossheaders showed that most of the activity was removed in the' first 10 to 15 minutes. Gamma decontamination factors of 4 to 8 were observed on spacers from an aluminum tube and 1.6 to 5 on anodized spacers from a $\mathrm{Zr}-2$ tube. Corresponding decontamination factors for gamma olus beta activity were 12 to 30 on spacers from an aluminum tube and 1.5 to 3.6 on spacers from $\mathrm{Zr}-2$ tubes. Final gama dose rates on the dummies ranged from 1.5 to $4 \mathrm{mR} / \mathrm{hr}$. Flushing the test crossheader with full front riser pressure ( 70 psi TORP) for a few minutes following the decontamination eliminated entrapment of activity in the rear nozzles, as was found during the previous single-tuoe, through-reactor tests. There was complete removal of observable product films and deposits from the fuel elements.

To date, there has been no indication of the through-reactor, or rearface decontamination wastes, or the dehydriding test wastes passing from the KE reactor trench, where the wastes were disposed, to the wells between the trench and the river. The wells and nearby springs will continue to be monitored.

\section{Zircaloy Process Tube Fydriding}

PTA-204, "Electrochemical Hydride Removal and Evaluation," was conducted February 25-27. 'Two tubes, 2255 and 3056, were removed for evaluation after they had been cleaned. Tube 2253 was stripped only, while 3056 was both stripped and etched. Hydride case was left on the surface of 2255 in the form of needles penetrating into the surface. One facet of this test is to determine if this small quantity of hydride would have ill effects on future tube performance. If all of this remaining case layer did subsequently diffuse into the base metal it would increase the base metal content about $100 \mathrm{ppm}$, which is a significant amount.
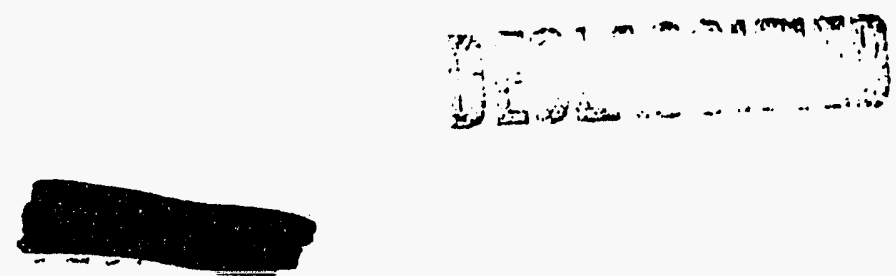
Tube 3056, which was both stripped and etched, was found to be completely free of any residual case layer. The etching step removed approximately 2 mils from the surface, and this was enough to eliminate all traces of case layer needles.

\section{K Concrete Shielding Examination}

The KN reactor top shield concrete test blocks, included in the original design, we.e removed on March 6 to determine if any substantial damage had occurred since initial startup on January 4, 1955. The blocks which were removed were tested for hardness with a "Schmit" hamer. The blocks had good resiliency with little indication of deterioration. There were no indications of crumbling.

New blocks were installed and the hole closed up on March 12.

Brittle Fracture Progiam - K Inlet Pioing.

\section{Technical Basis for Tube Power Limits}

A computer code to evaluate core voiding patterns for the calculation of $K$ reactor tube power limits is now ready for use. Trial runs with the program indicate that its application will permit elimination of some conservatism in limits that was previously unavoidable with manual evaluation procedures.

Present emphasis is on reevaluating post--accident flow and pressure transients in front crossheaders based on a wave mechanics approach. Upon availability of results early in April, work will start on ttechnical bases for operation of KE reactor at increased top-of-riser pressures.

\section{Product Flexibility}

\section{Pu-238 - Physics Stuiies of Thin-Annulus Neptunium Targets -}

Burnout, yield, and quality calculations were completed for two types of thin-annulus neptunium target elements, one with a vater core and the other with a graphite core. Calculated yields and qualities as a function of time vere comparable in the two cases, but burnout was calculated to be nigher in the wate: core, with conversion efficiency thus lower. Results rere documented as DUI-6841, "Conversion Calculations for Thin-Annulus Neptunium Element Design," A. F. Kupinski, llarch 23, 1970; (Secret). Calculation of Pu-236 buildup in thin-annulus elements is currently under way. 
Environmental and Regulatory Technology

\section{KW Reactor Deactivation - Effect on KE Reactor}

A study was ccoducted to determine if the deactivation of KT reactor would have any effect on the safety status of $K E$ reactor. It was determined that, following the deastivation of the $K \mathrm{~W}$ boilers, the "continuity of coolant supply criteria" could not be met without plant modifications. With both $K$ reactors in operation, the criteria assumed that the BPA powered primary coolant system would be lost at both reactors, and the steam powered secondary coolant system would be lost at one reactor. Under these conditions, the reactor which lost both primary and secondary systems would still be assured a continuous coolant supply tinrough the last-ditch diesel system. The diesels draw from the clearvells, and depend upon the operation of electrically powered river pumps to get a continuous supply to the clearwells. Followins shutdown of KII reactor and deactivation of tine KN boilers, there would be no means of providing coolant to the KE clearwells (assuming loss of jota primary and secondary systems at $\mathrm{KE}$ ) unless some alternate power source was made available.

To comply with the requirement for an indefinite supply of water to tine diesel system, the following alternatives are being investigated. First, tecinniques are being evaluated to make the water in the sedimentation basins available to the clearwells, assuming loss of both primary and secondary systems. This will provide a stored capacity of coolant to the diesels for a seven-day shutdown flow. Second, studies are in progress to identify the action which would be taken during this seven-day period to assure that a continuous supply of coolant, for an indefinite period of time, would be available by tine end of seven days.

\section{EFFLUENT ACTIVITY}

The coolant water alum feed rate was maintained at $13.4 \mathrm{ppm}$. The pH averaged 6.76 . The sodium dichromate feed rate was 0.56 .

Concentration of significant isotopes in the effluent are listed below and, for comparison, the concentration for the same month in the previous two years. Concentrations are in picocuries per milliliter. The fact that all isotopes measured in ilarch 1970 are substantially lower than in March 1968 and 1969 is attributed to the long (seven-week) outage just preceding the one week of operation last month.
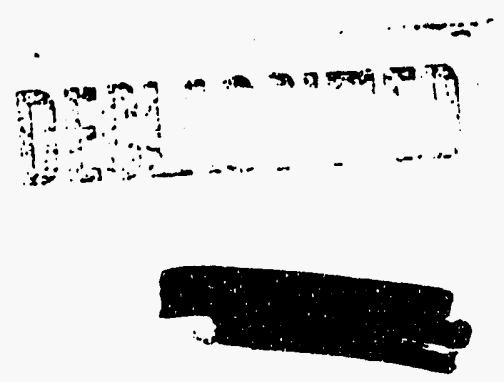
Files

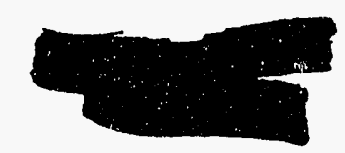

$\begin{array}{lrccccc} & \text { P-32 } & \text { As-76 } & \text { Np-239 } & \text { Cr-51 } & \text { Sc-46 } & \text { Zn-65 (Jan.) } \\ 1970 * & 4.2 & 44 & 30 & 48 & 6.0 & 12.9 \\ 1969 & 10.1 & 97 & 96 & 89 & 7.7 & 10.0 \\ 1968 & 16.5 & 133 & 127 & 161 \ldots & * * & 7.6\end{array}$

*:easurements cover tine one week of reactor operation in Narch 1070 **iro measurements

\section{IRRADIATION SERVICES}

\section{Production of Xe-128 for Argonne National Laboratory}

Separation and recovery of $210 \mathrm{scc}$ of Xe-128 from an irradiated target capsule containing 450 grams of elemental iodine has been accomplished for the Xe-128 development work requested by Argonne National Laboratory. Product yield was within five percent of the calculated yield. Analysis of the product revealed $\mathrm{CO}_{2}$ contamination in excess of the one percent maximum specified, and also a small amount of radioactive Ke-129. The Xe-129 presents no problem because of its relatively short. half-life ( 8 days). Plans are being made to remove the $\mathrm{CO}_{2}$ by utilizing the freezing point difference between xenon and $\mathrm{CO}_{2} \cdot{ }^{2}$

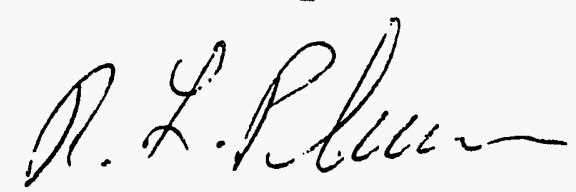

OR:RLP : RBS

R. L. Plurn, Chief Production Reactor Branch Production Reactor Division 


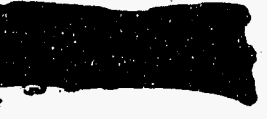

OUTACES (IIES.)

Reason

Charge-Discharge

Rupture Removal

Leali Testing

Tube Replacement

Maintenance

Standard Check

Production Tests

Whe Joint work

165 Boiler Fiame out

Total
$\underline{\mathrm{K}^{\prime} \mathrm{E}}$

$\underline{\mathrm{KW}}$

4.0
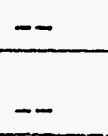

$-$

133.0

10.0

$--$

378.8

52.5

578.3
Total
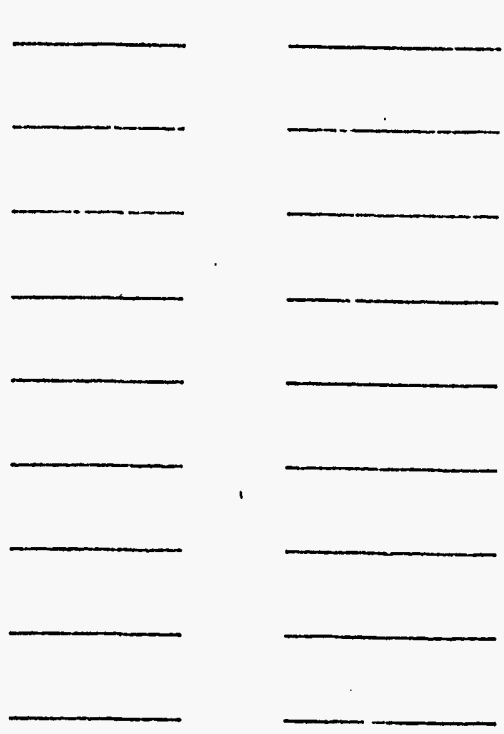


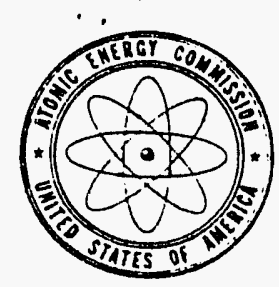

\section{UNITED STATES \\ ATOMIC ENERGY COMMISSION 4.}

RICHLAND OPERATIONS OFFICE

P. O. BOX 550

RICHLAND, WASHINGTON 99352

PRD-102 2

March 10, 1970

HANFORD CATEGORY …… ?

Files

MONTHLY REPORT FOR FESTUARY 1970

THIS DOCUMENT CONSISTS OF G FAGES

SUMRARY :"

KW reactor was shut down on February 1 to begin deactivation work. At month end deactivation isas 98 percent completed.

Ke reactor was shut down on February 1 for an extended maintenance outage for the replacement of four $24^{\prime \prime} \times 36^{\prime \prime}$ wye joints in the inlet coolant piping.

A rear face hardware internal decontamination reduced the maximum radiation level from $300 \mathrm{mr} / \mathrm{hr}$. to $130 \mathrm{mr} / \mathrm{hr}$.

Studies are being conducted to determine if bauxite is a significant source of scandium-45, the precursor to scandium-46, the latter thought to be a major contributor to the rear-face radiation dose rates.

The calculated limiting case for plutonium irradiations under existing nuclear safety criteria was about $50 \mathrm{~kg}$. for a natural uranium loading.

A wild duck shot at the 100-K disposal trench was found to contain undesirably large amounts of radioisotopes, primarily P-32.

REACTOR OUTAGES

KW -- The reactor was shut down at 0001 on February 1 to begin deactivation work. Discharge was completed on February 15. Storage basin water and sanitary water are being supplied from $\mathrm{kE}$ area.

KE -- The reactor was shut down at 0720 on February I. for an extended outage to replace the four $24 " x 36$ " wye joints in the primary coolant inlet piping. By month end all four joints were installed, heat treated, and radiographed. Also completed during tine outage was maintenance or replacement

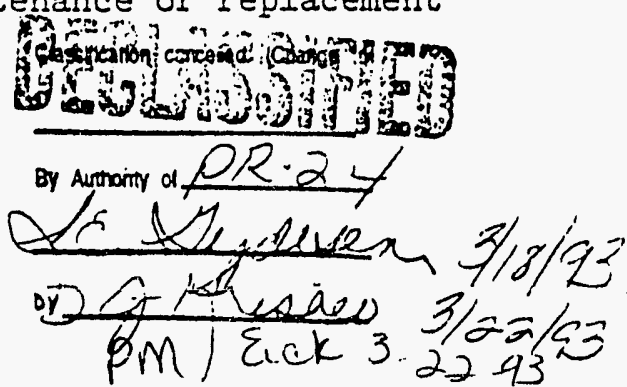




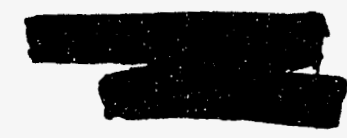

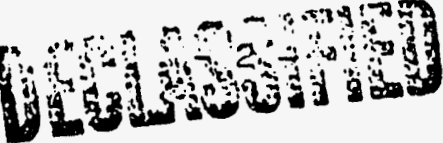

$\operatorname{Sarch} 10,1970$

of 3 control rods and 5 safety rods, minor maintenance on

the fuel pici-up cinte conveyor; rear face leair repair; production tests on zirconium hydride removal and through reactor decontamination; replacement of 117 particulate filters; replacement of 17 aluminum process tubes.

\section{EQUIP:ENT EXPERIENCE}

Boiler Operation - 165

Wodifications to the control mecianism on $\mathrm{Ho}$. I $\mathrm{kJ}$ Boiler (the last of six boilers in tile $K$ Areas) were completed. Post modification tests were conducted by the Becinan Instrument Company.

Vertical Safety Rods - RE Reactor

Five flexiole vertical safety rods were installed. All five channels were borescoped prior to installing the rods.

Horizontal Control Rods - KE Reactor

The Ho. 12 HCR was replaced with a cooled flat rod. The step-plug on the No. $7 \mathrm{HCR}$ was replaced with a modified step-plug and the tip section of the rod was replaced because of a deformation. The No. 8 HCR has been removed, and the channel is being prepared for a flat-cooled HCR.

Rear Face Internal Hardware Decontamination - KE Reactor

A rear face hardware internal decontamination was performed on February 20. The average rear face radiation level was reduced from $163.5 \mathrm{mr} / \mathrm{hr}$. to $47.6 \mathrm{mr} / \mathrm{hr}$. The maximum radiation level was reduced from $300 \mathrm{mr} / \mathrm{hr}$. to $130 \mathrm{mr} / \mathrm{hr}$.

\section{PROCESS TECHINOLOGY}

Uncooled Sorizontal Control Rod

After one year of operation in KE reactor the uncooled HCR was removed For evaluation. Those segments ( 40 inches each) of the rod that normally operated in the nost severely distorted section of the HCR channel revealed $3 / 8$ inch bowing. Some minor bowing due to creep was expected. The rod sheath (Inconel-600) was tarnished due to oxidizing of the surface in a high temperature environment. Operation with the rod has been trouble free.

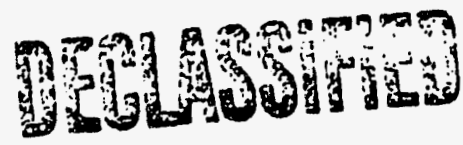


Harch 10,1970

\section{Rear-Face Dose Rate Stuay 1}

Scandium- 46 is assumed to be a major contributor to increased rear-face radiation dose rates experienced over the past few years at tile $K$ reactors. KE reactor was operated for one day with half of the reactor cooled with water treated witi liquid alum and half treated with the normal bauxite as the flocculating agent. Samples of coolant were taken from each half of the reactor and are being analyzed to determine if bauxite is contributing parent scandium.

\section{Turnaround of KW Graphite Stack}

Contrary to predictions based on core samples irradiated in the ETR, $K W$ reactor has shown a decreasing contraction rate during the past year. Recent measurements confirm that turnaround has occurred in the high flux center region and expansion is now occurring. The KN turnaround occurred at an exposure of $7 \times 10^{21}$ nvt and 2.4 percent contraction compared to turnaround of the above core samples at $11 \times 10^{21}$ nvt and 3.5 percent contraction. At this time no explanation can be made for the difference in behavior.

Turnaround has not yet been observed at $\mathrm{KE}$ reactor, which continues to contract linearly with exposure. The exposure of the $\mathrm{KE}$ stack is similar to that of $\mathrm{KW}$.

\section{Brittle Fracture}

After reviewing the riser pressure proof test with DRL it was agreed that successful completion of the proof test would permit operation at full pressure on dual-riser failure limits. This will be a static test. Evaluation of the effects of dymamic loading continues.

\section{RESEARCH AND DEVELOPMENT}

\section{Basic Production}

Brittle Fracture Program - $K$ Inlet Pipins

\section{$\dddot{\Upsilon}$ Limits Physics Studies}

Physics calculations in support of the dual riser failure analysis under current operating conditions have been completed and sensitivity analyses of the various parameters are being performed. 
Product Flexibility

\section{High Enrichment Utilization Studies}

\section{PuAl Loading Limitations}

The calculated limit of plutonium-aluminum fuel that could be charged under existing nuclear safety criteria, i.e., speed of control and total control, is $50 \pm 5 \mathrm{~kg}$. and $75 \pm 15 \mathrm{~kg}$., respectively, within a normal uranium loading. It is assumed that the PuAl columns would be scattered throughout the central zone of the reactor to preclude formation of a post-meltdown critical mass. The net meltdown effect of both the normal uranium loading and the PuAl diffusion into the graphite stack would be strongly negative.

\section{$\underline{\text { Pu-238 }}$}

Development work on the thin annulus target design for neptunium irradiation has concentrated on pressing and sintering cermet rings using $\mathrm{UO}_{2}$ as a stand-in for $\mathrm{NpO}_{2}$. Component design and target assembly procedures are nearing completion. The in-reactor loading configuration will be a $2 \times 2$ cluster, planned for charging into $K \mathbb{E}$ reactor during the fourth quarter of FY-1970.

Waste Management

\section{K Reactor Effluents}

A recent report on radiologic aspects of ground cisposal of $\mathrm{K}$ reactor effluents shows that soil retention of radionuclides associated witi a ten-year continuous operation span of a $K$ reactor and subsequent complete release to the river in one day would not, after dilution, produce concentrations in the river that would exceed the limits specified in 10 CFR 20 limits for routine releases.

It is concluded that the potential for an uncontrolled release of stored radionuclides does not preclude ground disposal of effluent from operation of a $K$ reactor.

\section{Contaminated Naterforl}

A wild duck taken at the $100-K$ disposal trench Decembe:" 29 was found to contain undesirably large amounts of radioisotopes, primarily P-32. 
March 10, 1970

\begin{abstract}
Other ducks and a coot were sampled later in this area and found to have less but still undesirable contamination. The concern is that these are migratory game birds that could be shot and eaten by people. Action is being taken to prevent reactor effluent from reaching the ditch in the future and to treat the ditch water with copper sulfate to kill the algae in tile ditcin that apparently are attracting the ducks. Other steps being consiciered include filling tise trencil with boulders and covering it over with wire netting.
\end{abstract}

\title{
EFFLUENT ACTIVITY
}

Because of the shutdown of both $K$ reactors, no effluent data were obtained during the month.

\section{SPECIAL IRRADIATIONS}

\section{Production of Xe-128 for Argonne National Laboratory}

Trial separation runs using natural xenon and elemental iodine have been performed for the $\mathrm{xe}-128$ development and production work requested by Argonne iNational Laboratory. Results of these tests indicate that xenon recovery greater than 99 percent can be attained with product impurities of less than 1 percent. The target capsule containing 450 grams of iodine has been discharged and transferred to the storage basin. Final preparations are now being completed to perform the separation and recovery run using the irradiated target capsule. Approximately $150 \mathrm{ml}$ of $\mathrm{xe}-128$ are expected to be produced from this source.

\section{Isotope Production}

\section{Hafnium-181 Production, Portland State Lniversity}

Aismall sample of hafnium oxide was irradiated in a quickie facility at KN reactor to produce 16 millicuries of hafnium-181 for a calibration source.

\section{Viaterial Testing}

The second in a series of uranium oxide creep rate tests for Battelle Northwest was run in the KV reactor snout facility. This is in support of the LiFBR program.

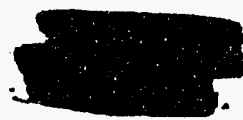




\section{Routine Irradiations}

The last two of a series of boron carbide capsules were discharged from a $k W$ reactor general purpose facility. Capsule number two had reached goal exposure, but capsule number tinree was discharged early due to the KT reactor shutdown.

Tiree cold tensile specimen capsules vere removed from the kil reactor snout and shipped to the customer for analysis. The remaining six capsules will be recharged in $\mathrm{KE}$ reactor.

One hundred sixty-nine quickie activation analysis capsules were irradiated in the $K$ reactor quickie facilities for periods of from 10 minutes to several hours.

OR:DISIS

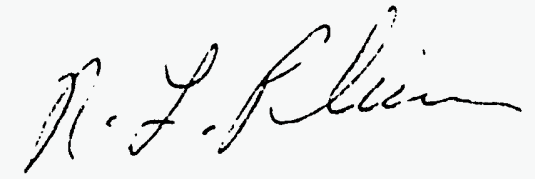

R. L. Plum, Chief Production Reactor Branci Production Reactor Division 


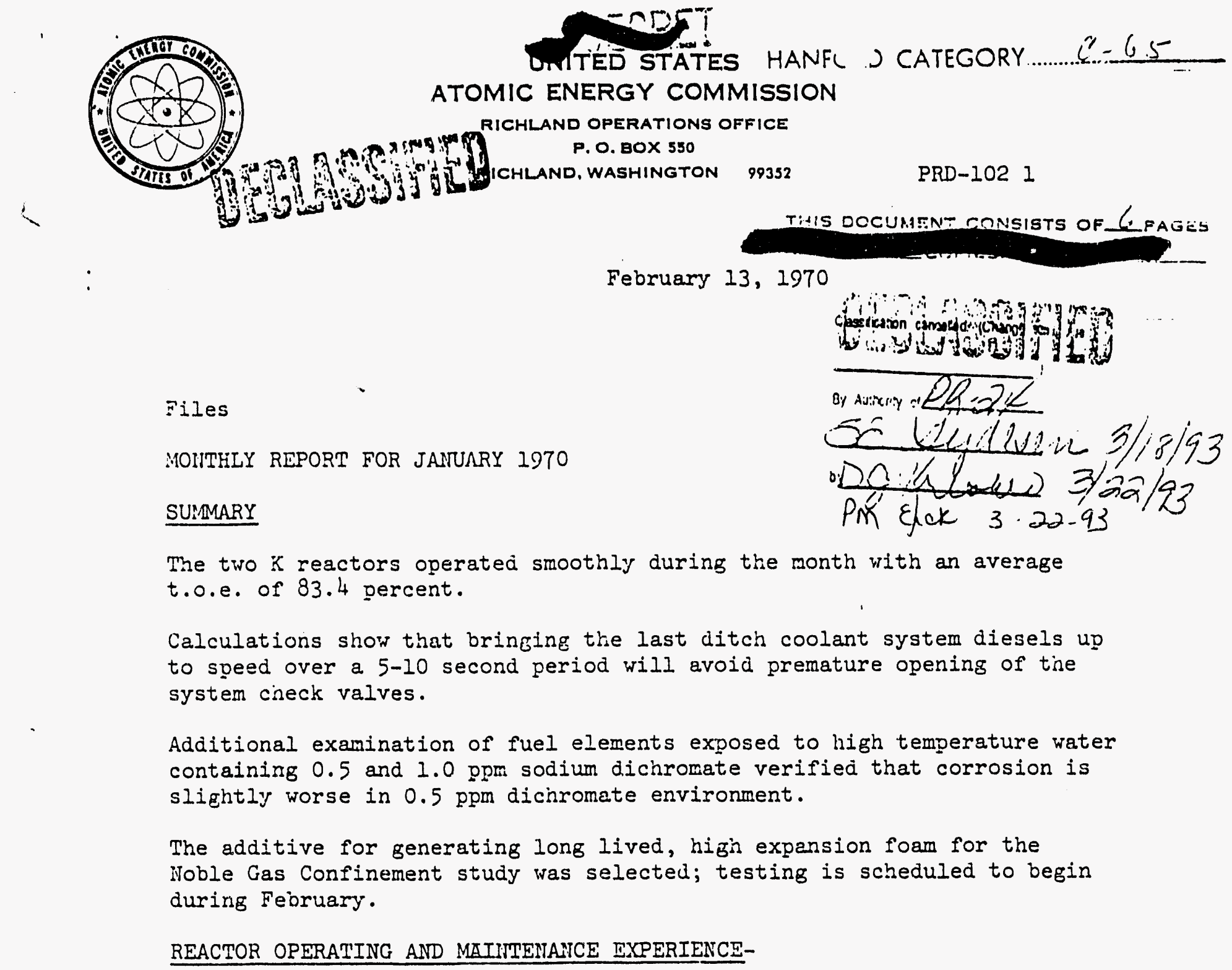

\section{Operations}

Input Prod. KIWD

of of Forecast

TOE

Operational Limitation

Fuptures :

ilormal

94

\begin{tabular}{crr} 
KE & KW & Total \\
\hline & & \\
109.4 & 94.6 & 204.0 \\
181.5 & 102.1 & 133.4 \\
89.5 & 77.4 & 83.4 \\
4000 & 4000 &
\end{tabular}

laintenance

Water Leaks
Van Stone
Internal

Process Tubes Replaced
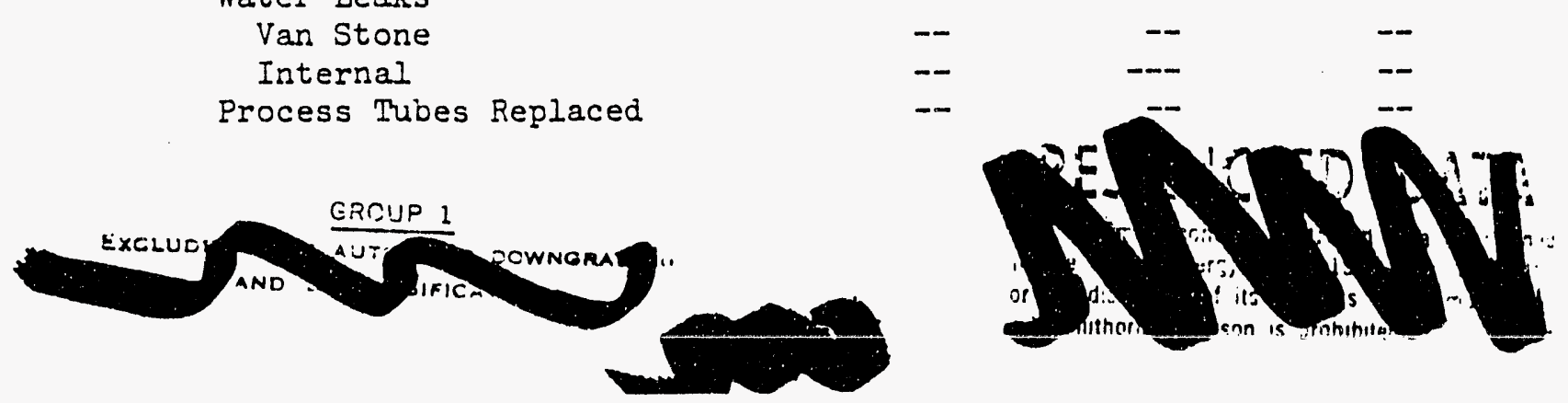
Ruptures:

None

EQUIPMENT EXPERIENCE

Resistance Temperature Detectors - KE Reactor

An analysis of data obtained during the January 14 shutdown sioned approximately 400 RTDs with response times greater than 3.0 seconds. These RTDs will be tested and replaced as necessary during the lye joint outage.

\section{REACTOR: OUTACES}

Date Date Outage

Do:m UD Hours

KE PEACTOR
$1 / 1$
$1 / 8$
168.3
Scheduled charge-discharge and maintenance.

KS REACTOR

$1 / 14 \quad 1 / 17 \quad 78.1 \quad$ Scheduled charge-discharge.

\section{RESEARCH AIID DEVELOPWEIT}

Basic Production

Through-Reactor Decontamination

Iiquid samples were taken at several locations in the 100-K Area between the trenci and the river. Analysis of these samples for $\mathrm{pH}$ and radioisotope content will provide control data for the single crossheader decontamination test to be conducted at KE reactor during the wye joint replacement outage. Additional liquia samples from the same locations will be taken following the test. Their analysis will be compared to the analytical model for tise movement of ground discharged decontaminating solutions.

Half-Plant Dichroriate Test

Examination of the fuel elements exposed to coolant containing $0.5 \mathrm{ppm}$ and $1.0 \mathrm{ppm}$ sodium dichromate in a half-plant test in $\mathrm{k} / \mathrm{W}$ reactor verified earlier observations that at the higher temperatures corrosion was 
severe in both environments but slightly worst at $0.5 \mathrm{ppm}$ dichromate. A very pronounced dependence of localized corrosion on temperature was found. At 90-95 C tube outlet temperature only uniform corrosion was ooserved. At 100-105 C extensive shallow ledge corrosion on the fuel bottom lateral surfaces and slight erosion-corrosion at the bottom supports was observed. At 107-108 C groove corrosion was comencing on the bottom lateral surfaces and most of the support crowns were severely corroded. Support corrosion increased from very severe at $112 \mathrm{C}$ outlet to complete removal at $115 \mathrm{C}$ outlet and groove corrosion of the lateral bottom clad surfaces penetrated to the AlSi layer. Exposure ranged from 850 to $1250 \mathrm{lWW} / \mathrm{T}$ during a total of 82 day - of testing.

\section{Segmental Discharge Studies}

Recent analyses of segmental discharge operation has confirmed that there is reduced fuel throughput for a constant Pu-240 content. Six percent Pu-240 material produced in the segmental discharge mode would contain approximately 10 percent less Pu-241 than plutonium currently produced.

\section{Product Flexibility}

Pu-238

\section{Np Irradiation}

A.nominal 200 grams of neptunium oxide and graphite wafers contained in eight target elements were irradiated in a KW reactor central zone column during January. The wafers will be examined in PNL facilities for dimensional stability under irradiation to identify the critical fabrication parameters pertinent to growth.

Two neptunium-graphite samples were sent to ARHCO for an independent determination of tineir Pu-236/Pu-238 weight ratio. Arrangements are also being made for independent analyses of IIpAl elements to provide aditional irformation on the success of the clustering technique on reducing Pu-236 contamination.

The calculations of yield and quality oredictions for Pu-238 produced in thin-annulus elements show the graphite-core element to be tie more efficient Pu-238 producer, but the water-core element vill produce Pu-238 at 90 percent qualitj more rapidily. 
Noble Gas Removal

-.. Research on developing additives that would produce long lived foams was concluded during January. Testing of both selected additives and cryogenic techniques will begin in February.

The most promising foam additive is two parts polyethqleneamine, one part polyvinylalcohol, two parts foaming agent and fife parts water. This material mixes readily with water and no separation of the solution has been noted after 30 days. Thus, storage of the mixed foaming agent appears practical over a long period.

The foam tested to date have experienced a degradation rate of about one inch per week. The foam exhibits a two-thirds solution runoff in a few hours. The runoff has been used to produce additional foam with the same properties as the initial foam. The foam bubbles appear to set into a sticky semiplastic state. Upon intentional rupture, the bubbles do not burst, but rather slowly collapse as the contained gas escapes through the point of rupture.

\section{PROCESS TECHNOLOGY}

Pressure Surges in the K Reactor Fmergency Crosstie

Assuming the presence of air in each end of the crosstie line, calculations predict the pressure peaks shown below for the indicated diesel acceleration rates:

Peak Pressure - PSIA

\begin{tabular}{|c|c|c|c|}
\hline Reactor & Instantaneous & 10 Seconds & 20 Seconds \\
\hline $\mathrm{K} C \mathrm{~N}$ & 654 & 330 & 220 \\
\hline
\end{tabular}

A peak pressure of 410 psia is necessary to open the A-B riser check valves for current TOR.P.

Experiments will be conducted to substantiate the calculations.

EFFLUENT ACTIVITY DATA

The alum feed rate was maintained at $15.9 \mathrm{ppm}$ and $14.7 \mathrm{ppm}$ at $\mathrm{KE}$ and $\mathrm{KN}$, respectively. The coolant $\mathrm{pH}$ averaged 6.74 and 6.66 at $\mathrm{KE}$ and $\mathrm{KW}$, respectively. The sodium dichromate feed rate was $0.50 \mathrm{ppm}$ at both $\mathrm{KE}$ and $K T$.

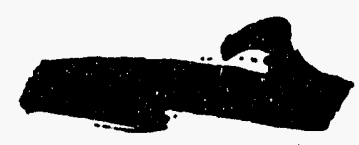


Files $5-5$ February 13, 1970

The phosphorus-32 and arsenic-76 concentrations in the effluent for this month are shown below, along with some historical data.

\begin{tabular}{|c|c|c|c|c|c|}
\hline \multicolumn{3}{|c|}{$\begin{array}{c}\text { Phosphorus }-32 \\
\text { pCi/ml }\end{array}$} & \multicolumn{3}{|c|}{$\begin{array}{c}\text { Arsenic }-76 \\
\mathrm{pC} i / \mathrm{ml}\end{array}$} \\
\hline KE & $\mathrm{Kh}$ & Ave. & KE & $\mathrm{KI}$ & Ave. \\
\hline 2.2 & 3.2 & 2.7 & 39 & 50 & 49 \\
\hline 4.9 & 3.1 & 4.0 & 82 & 73 & 78 \\
\hline 6.4 & 8.6 & 7.5 & 73 & 66 & 70 \\
\hline 8.9 & 5.3 & 7.1 & 123 & 106 & 115 \\
\hline
\end{tabular}

Other isotope measurements for the ronth in $10^{-12}$ curies per milliliter:

$\begin{array}{lllll}\text { Reactor } & \text { ND-239 } & \text { Cr-5I } & \text { Sc-46 } & \text { Zn-65 (Dec.) } \\ & 51 & 82 & 7.0 & 9.9 \\ \text { KN } & 62 & 90 & 9.0 & 8.6\end{array}$

The lower P-32 and As-76 may be caused by the rise in pH (reduced acid addition) during the cold water period. The current operating mode is to adjust $\mathrm{pH}$ and diciromate to a tolerabie fuel corrosion rate.

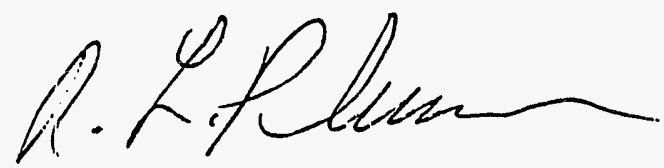

OR:DMS : RBS

R. L. Plum, Chief

Froduction Reactor Branch

Froduction Reactor Division 


\section{OUTKGES (IIRS. )}

Reason

Charge-Discharge

Rupture Removal

Jeak Tostim

Tube Replacoment (Provolosing)

Mainlenance:

Standard Check

Production Tests

Project Work

Miscellancous

Total $\underline{\text { KE }}$

$\underline{K l I}$

59.3

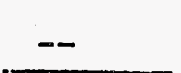

$-$

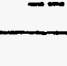

5.4

3.8

6.5

3.1

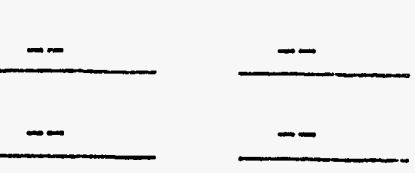

78.1
36.4
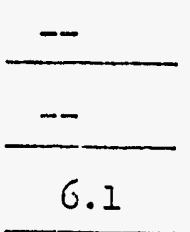

14.6

104.7

6.6

163.4
Total

$95.7-{ }_{-1}$

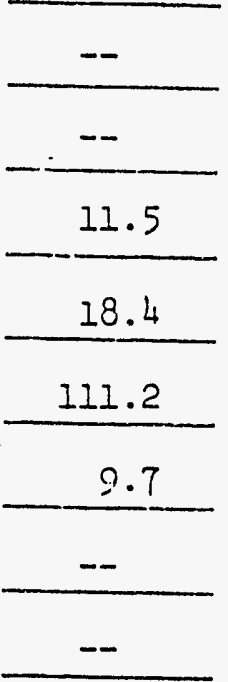

246.5 


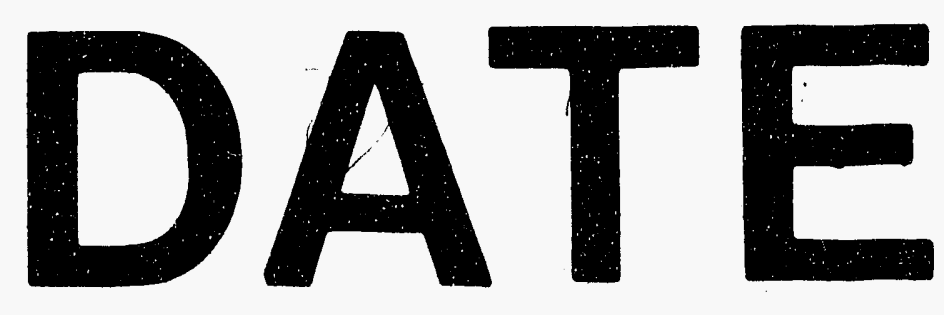

1
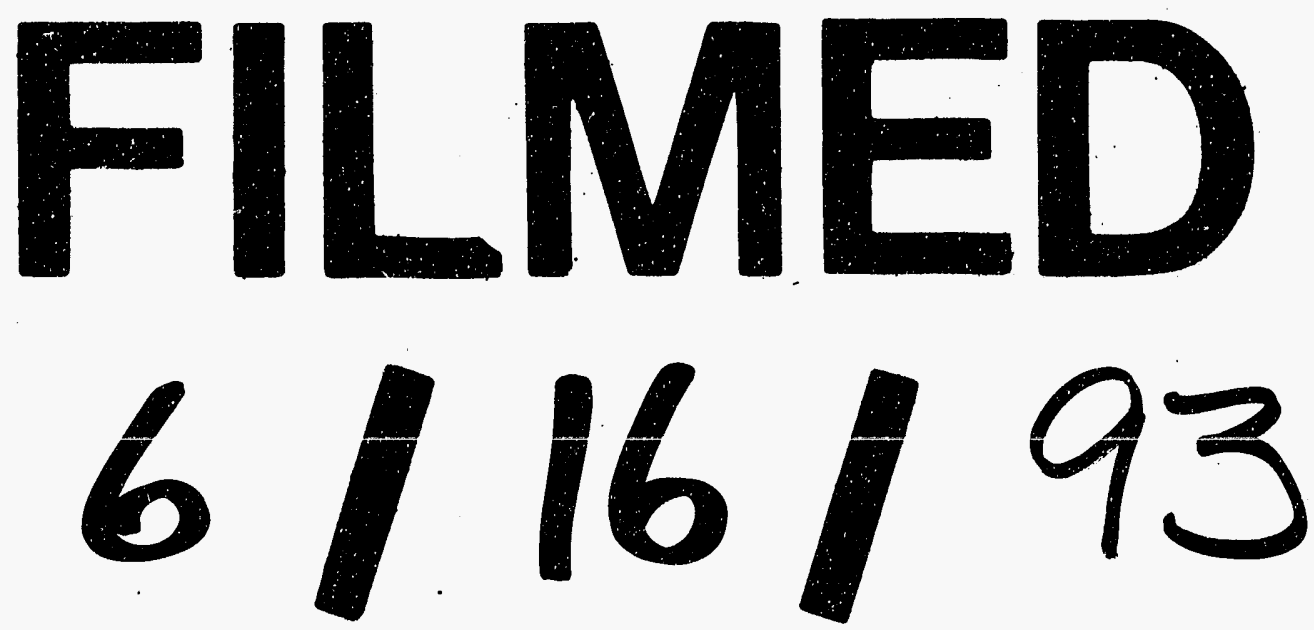
